\title{
ECONOMICS
}

\section{Intangible Capital Distribution in China}

by

\section{Qing Li}

Long H. Vo

and

\section{Yanrui Wu}

Business School

The University of Western Australia 


\title{
Intangible Capital Distribution in China
}

\author{
Qing Li, Long H. Vo, and Yanrui $\mathrm{Wu}^{*}$ \\ Economics Department \\ Business School, University of Western Australia
}

\begin{abstract}
Our main argument in this paper is that conventional growth convergence analysis in China is incomplete without considering intangible investment. We first document the unbalanced investment of intangible capital across Chinese regions. A few mega cities invest heavily in intangible capital, while the majority of regions have below-average investment levels. In addition, long-term convergence clusters is an important feature of intangible capital distribution: High levels of investment tend to be persistently concentrated in the few coastal regions while investment in poorer regions is projected to be low, leading to a longrun distribution with probability mass located at levels much lower than the national average. External shocks such as the global financial crisis can exert an adverse effect: The level to which most regions converge based on the post-crisis transition dynamics is lower than that based on the pre-crisis dynamics. Finally, we document that poorer regions have less difficulty in converging to the average level of their neighbouring regions, suggesting that knowledge spill-overs is an important mechanism that help mitigate the level of unbalance in the context of intangible economy.
\end{abstract}

Key words: Economic growth convergence; Intangible capital; Distribution dynamics; Mobility probability

JEL Classifications: O10, R11, C14.

\footnotetext{
*Acknowledgements: Qing Li acknowledges financial support from UWA China SIRF Scholarship. Long Vo receives support from the International Research Training Program at the University of Western Australia. All errors remain with the authors.
} 


\section{Introduction}

Intangible capital, together with labour force and physical capital, constitutes the three most important input factors in the expand production function. Measuring intangible investment and its capital formation is therefore critical to understanding the driving force of economic and productivity growth. ${ }^{1}$ Figure 1.1 illustrates the progress over the last two decades of an important category in intangible capital, namely research and development (hereafter R\&D), for China, the US and the world. From panel A it can be observed that China's R\&D investment (expressed in \% of GDP) is rising fast and converging to the world level, while in the US the investment level is relatively stable over time. The growth rate of R\&D investment, as shown in panel $\mathrm{B}$, exhibits considerable volatility during this period for all countries. Although investment is slowing down recently for China, we still observe high and persistently positive growth rate for this country, as opposed to much lower growth rates for the US and for the world as a whole.

Figure 1.1 Research and Development Expenditure, Selected Countries, 1996 - 2015

\section{A. $R \& D$ expenditure}

$\mathrm{R} \& \mathrm{D}$ expenditure (\% of GDP)

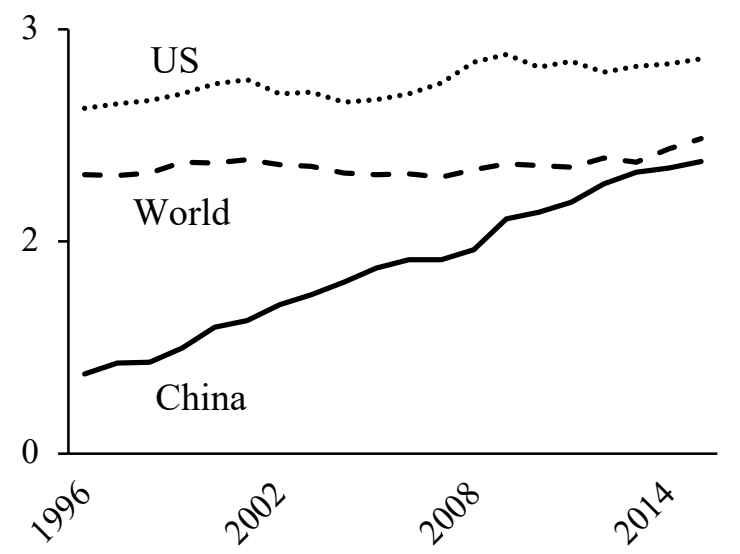

B. R\&D growth rate

$R \& D$ expenditure growth rate $(100 \times \log$ difference $)$

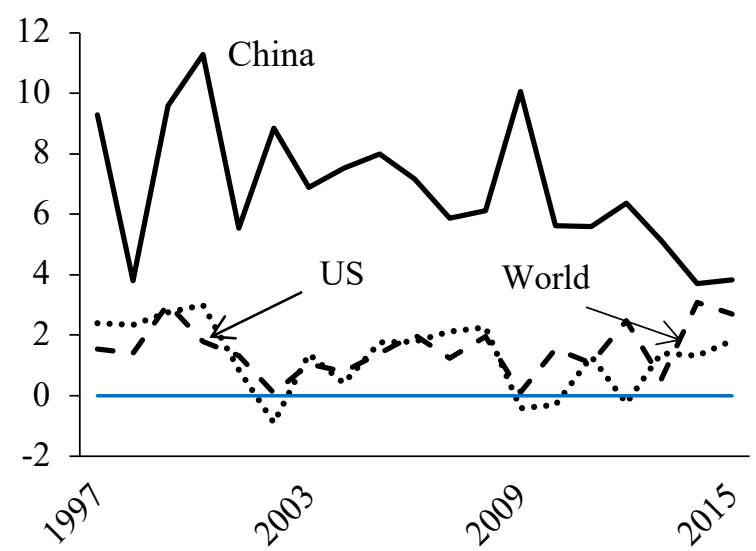

Notes: This figure presents the time-series of the expenditure for research and development as percentage of GDP (panel A) and its growth rate (panel B) for China, the US, and all countries (including these two) during the period $1996-2015$.

Source: World Development Indicators (World Bank, 2018) and author's calculations.

The role of intangible capital in China's regional development can be linked to the classical theory of external economies of scale. Traditionally, there are two types of economic development patterns, namely, localization and urbanization economies, that are

\footnotetext{
${ }^{1}$ Intangible capital is not a novel concept in the modern world of knowledge economy. Some examples of intangible capital are the software developed by tech giants such as Microsoft Inc. and Coca-Cola's famous coke recipe which dates back to the late $19^{\text {th }}$ century. Such innovation brought large streams of revenue for these firms and contributes significantly to the growth of the US economy. However, due to measurement difficulty, intangible capital has conventionally been treated as an immediate expense, rather than an investment, and has been ignored at both firm-level and national account balances (Jona-Lasinio et al., 2011).
} 
considered to exhibit external economies of scale (Rosenthal and Strange, 2004). As far back as the $19^{\text {th }}$ century, British economist Alfred Marshall, who was at the time struck by the phenomenon of geographical concentration of single industries (i.e., localization economies) that cannot be explained by natural resource endowments alone, conjectured that such behaviour is the combined result of specialized suppliers, labour market pooling and knowledge spill-overs (Krugman et al., 2018). ${ }^{2}$ In recent times, regions that rely on a single industry is found to do worse than regions with a range of industries, giving rise to the concept of urbanization economies (Haskel and Westlake, 2018). According to Glaeser $(1999,2012)$, the concentration of people and firms in cities is more of a result of innovation and invention than of the demand for mass production of goods. This implies that intangible capital, as the "carrier" of knowledge and innovation, could act as a catalyst for external economies of scale. ${ }^{3}$ Due to its role in facilitating external economies of scale, intangible capital is expected to fuel China's diverse and growing coastal regions where large innovation hubs are located. Once the economies of scale are obtained, they in turn attract more intangible capital. Our results imply that this type of "self-fulfilling" process worsens the existing unbalanced intangible capital investment and will eventually push up regional inequality in China.

The aim of this paper is to understand the distribution dynamics of China's intangible capital. Following the framework of Corrado, Hulten and Sichel $(2005,2006)$ (hereafter CHS), we first measure the intangible capital investment and examine its distribution across 31 Chinese provinces. A non-parametric approach is then adopted to project the current distribution into the future. An ergodic distribution is estimated to illustrate the long-run stationary development of intangible investment in China. Additionally, spatial and intertemporal distribution dynamics are examined by partitioning our data into sub-periods and sub-regional groups. Finally, since geography can be a possible explanatory channel for intangible spill-over, we study the distribution conditioned on distances between regions.

\footnotetext{
${ }^{2}$ Examples of such localized economies in developed countries include Silicon Valley (high-tech), Hollywood (movie making), and London and New York (finance service). Equivalence in China includes Zhongguancun in Beijing (high-tech), Haining in Zhejiang (leatherwork) and Hengdian World Studios in Zhejiang (movie making). Following Marshall's initial observation, knowledge spill-overs within single industry were explored by Kenneth Arrow (Arrow, 1962) and Paul Romer (Romer, 1986), hence the well-known term MarshallArrow-Romer effect (Carlino, 2001).

${ }^{3}$ Glaeser attributes the booming of urban population density to the knowledge spill-overs across different industries (i.e. the so-called "Jacobs spill-overs" effect, in honour of urbanist Jane Jacobs's description of human capital spill-over from shipbuilding to auto industry in Detroit in 1969). According to this theory, the growing of cities attracts people with various backgrounds, facilitates face-to-face interaction, spurs innovation, and encourages the exchange of ideas. What Glaeser describes is essentially in line with the concept of intangible economy.
} 
We contribute to the literature in multiple distinct aspects. Firstly, to our best knowledge, this is the first study that examines Chinese intangible capital distribution dynamics at the regional level. Utilizing novel data, we provide evidence of the unbalanced development of intangible assets in Chinese regions. Second, in terms of methodology, we augment the non-parametric approach of Cheong and $\mathrm{Wu}(2013,2014)$ by adding a bootstrap confidence interval to the estimates of transition probabilities, thus allowing us to examine the mobility of regions with greater confidence than in previous studies. Third, sub-period and sub-sample analyses indicate that the global financial crisis exerts a significant impact on intangible investment in China, especially in intangible-intensive regions. Fourth, a large investment gap is detected between the coastal and interior regions: Coastal regions are expected to outperform the rest of China in the long-run in terms of intangible investment. Finally, knowledge spill-over is observed to be an important channel determining the convergence towards the average investment levels exhibited by neighbouring regions.

The rest of this paper is organized as follows. Section 2 reviews the literature on intangible capital globally and in China. The measurement of intangible capital and provides an overview of the shape of capital distribution are topics of section 3. Section 4 discusses the non-parametric approach to distribution dynamics analysis. The results based on the full sample, sub-periods, economic zones, and spatial factors are reported in Section 5. Section 6 concludes the paper and provides policy implications.

\section{Literature review}

In this study, intangible capital refers to the knowledge embodied in intangible products or processes that can be transferred into the market, such as scientific R\&D, patents, licenses, artistic originals and so on. The concept is fundamentally different from what we normally identify as "human intangible capital" that indicates knowledge created by labour force and encapsulated by employment. Intangible capital also differs from "technological intangible capital" that represents inspiration, serendipity and costless technique progress ( $\mathrm{Li}$ and $\mathrm{Wu}, 2017$ ). Currently, the invisibility and unaccountability nature of intangible capital poses a serious impediment to its measurement in China, not to mention data availability. Only one category of intangible capital, namely R\&D, is currently reported, and only at the national level (see Figure 1.1). ${ }^{4}$ Measuring other types of intangible capital in China, such as computer software, copyrights and patents, and organizational capital is a daunting task. Because of the lack of measurement theory and data constraint, the current

\footnotetext{
${ }^{4} \mathrm{R} \& \mathrm{D}$ is reported in China's national account only after a reform of the United Nations System of National Accounts in 2008 (known as SNA-2008) (NBS, 2017).
} 
literature yields limited insight with respect to the distribution of intangible capital, to the best of our knowledge. Pioneering works in the examination of aggregated intangible capital investment include Hulten and Hao (2012) and Tian et al. (2016), followed by Li and Wu (2017) who present the first study at the regional level.

According to Jona-Lasinio et al. (2011), the expenditure of intangible capital should be regarded as investment instead of immediate expenditure if it satisfies the following criteria: a) To be identifiable, that is, the investment can be separated, transferred, sold or rent; b) to have a clear ownership; c) to be profitable and d) yields profits last for more than one year. The CHS framework, which we adopt, categorizes the usual intangible capital into three broad groups: Computerized information, innovative property, and economic competency property. Computerized information indicates knowledge embedded in computer software and database. Innovative property indicates knowledge acquired through innovation activities, including scientific $R \& D$, mineral exploration and evaluation, entertainment and artistic originals, financial products and services, and architectural and engineering designs. Economic competency property refers to knowledge embedded in firmspecific assets, including advertising, market research, employer-provided training and organizational structure. ${ }^{5}$

Following CHS's work, a large strand of literature seeks to examine the impacts of intangible capital on economic and productivity growth. Corrado et al. (2009) found that the inclusion of intangible investment would increase the growth rate of output per hour by 10 to 20 percent in the non-farm sector in the US in the late 1990s. Van Ark et al. (2009) and Corrado et al., (2014) documented that the higher rate of investment in intangibles and contribution of intangible capital in service sector are associated with higher growth rates of GDP per capita and overall economic performance in the EU countries. Belhocine (2008) suggested that the growth in GDP and labour productivity is understated by approximately 0.1 percentage point in Canada when intangible capital is excluded. The lower investment in intangible capital is responsible for the productivity gap between Canada and the US (Baldwin et al., 2012). Studies in other economies such as Japan, Australia, Brazil all pointed to the fact that intangible capital accounts for an increasing share in GDP and contributes significantly to the output and/or productivity growth (e.g. Barnes and McClure, 2009; Dutz et al., 2012 and Fukao et al., 2009).

\footnotetext{
${ }^{5}$ Two types of intangible capital in the CHS framework, namely, expenditures of computer database and market research, have not been incorporated in this analysis due to data constraint. The measurements of intangible investment are consistent with the work of $\mathrm{Li}$ and $\mathrm{Wu}(2017)$.
} 
Only a few studies analyse intangible capital investment and its contributions in China in recent years. Also adopting the CHS framework, Hulten and Hao (2012) noted an increasing growth rate of intangible investment starting from 1990. During this period, China is still a manufacturing-oriented economy with a relative low ratio of intangible to tangible investment. Tian et al. (2016) highlighted the faster growth of intangibles during 2001-2012, but pointed out an unbalanced development structure: China invests heavily in computerized information and innovative properties, but underinvests in economic competency properties. $\mathrm{Li}$ and $\mathrm{Wu}(2017)$ examined intangible capital investment at China's provincial level, and find that when intangible capital is considered in growth accounting exercises, both the coastal and interior regions realize faster growth in labour productivity and have larger capital deepening effects. However, a wide gap in intangible investment between the coast and the interior is detected, suggesting evidence of intangible agglomeration.

Theoretically, the conventional production function can be expanded by incorporating intangible capital as additional capital input and intangible investment as additional component of output. ${ }^{6}$ Consequently, conventional income would be underestimated without consideration of intangible capital. The impact of total factor productivity (TFP) would also be diminished, and the labour's income share would be decreased when intangibles are counted as capital (Corrado et al., 2006, 2009). These arguments imply that the rising role of intangible capitalization necessitates a thorough revisit on classical economic problems, one among which is economic disparity and convergence. For example, neo-classical exogenous growth theory posits that capital accumulation is the source of conditional convergence, while divergence can stem from productivity differentials as determined by endogenous growth models (Kumar and Russell, 2002). However, for reasons outlined above, both capital deepening effect and technological effect would be ambiguous without accounting for intangible capital.

In addition to these issues, studies examining regional disparity development in China mainly take income per capita as the variable of interest, ${ }^{7}$ which may result in misleading implications because the income measure is underestimated, especially in intangible-intensive regions. Even though the transmission of intangible investment into China's GDP growth is currently difficult to estimate, we would expect the bias emerging from intangible omission to make a significant impact on GDP measures in the near future.

\footnotetext{
${ }^{6}$ For instance, China's National Bureau of Statistics revised national accounts by incorporating scientific R\&D since 1952 in June 2016. The revised GDP in 2016 is expanded by 1.3\%, with the annual growth rate being driven up by $0.4 \%$ (NBS, 2017).

${ }^{7}$ See, among many others, Cheong and Wu, 2013; Herrerías et al., 2011; Lemoine et al., 2015 and Sakamoto and Islam, 2008.
} 


\section{Overview of China's regional intangible capital intensity}

We are first interested in the distribution of the total intangible capital investment across Chinese regions. This investment is encapsulated in the sum of nine individual intangible asset classes listed in Table 3.1. These investments are deflated by the constant 2010 price, using category-specific deflators. Corresponding data sources and definitions of price deflators are also provided. Per capita value is calculated as the ratio of total intangible investments to provincial populations. This quantity is divided by its national mean to get the relative intangible capital intensity (hereafter, RICI). The descriptive statistics of regional RICI is reported in Table 3.2. As can be seen, the distribution of RICI is highly skewed to the right, indicating that a few regions are far ahead of the rest in term of intangible capital investment.

To reduce the data dispersion, we instead use the logarithmic transformation of RICI as our main variable of interest: Let $y_{i t}$ denote intangible capital intensity of province $i$ in year $\mathrm{t}$, and $\bar{y}_{t}=\frac{1}{N} \sum_{i=1}^{N} y_{i t}$ be the national average of $y_{i t} . N=31$ is the number of regions in our sample. The variable to be analysed in this study is:

$$
\mathrm{X}_{\mathrm{it}}=\ln \left(\frac{\mathrm{y}_{\mathrm{it}}}{\overline{\mathrm{y}}_{\mathrm{t}}}\right)=\ln \mathrm{y}_{\mathrm{it}}-\ln \overline{\mathrm{y}}_{\mathrm{t}} .
$$

This logarithmic transformation also has the advantage of simplifying the interpretation, while preserving the transition dynamics. Specifically, the value of $\mathrm{X}_{\mathrm{it}}$ indicates the distance from a province's intangible capital investment intensity to the national mean. If the distance is sufficiently small, the percentage difference between province i's investment and the national mean can be approximated by the logarithmic difference: $100 \times \mathrm{X}_{\mathrm{it}} \approx 100 \times$

$\frac{y_{i t}-\bar{y}_{t}}{\bar{y}_{t}} \cdot{ }^{8}$ Additionally, when $y_{i t}=\bar{y}_{t}, X_{i t}=0$. That is, the national average takes a value of zero when log-transformed. It follows that if the spatial dispersion of capital intensity is small/high (i.e. there is a strong convergence/divergence of the provincial investments), the values of $\mathrm{X}_{\mathrm{it}}$ will be tightly distributed/disperse around zero.

Figure 3.1 is a map that illustrates the spatial distribution of RICI in the first and last years in our sample. Provinces are color-coded based on the ranking of relative capital intensity, from low (light) to high (dark). There are two important observations emerging from this map: First, the inland provinces (which tend to be the poorer ones) starting out with lower-than-average investment, while the coastal provinces enjoy above-average investment. Second, after the course of 13 years, there appears to be a broad pattern of polarization at the national level, in that more inland provinces become less-intensive

\footnotetext{
${ }^{8}$ However, this approximation is not precise in case of large differences.
} 
Table 3.1 Categorizations, Measurements and Data Sources of Intangible Capital Investment

\begin{tabular}{|c|c|c|c|}
\hline $\begin{array}{c}\text { Intangible Capital Category } \\
(1)\end{array}$ & $\begin{array}{l}\text { Measurement } \\
\text { (2) }\end{array}$ & $\begin{array}{c}\text { Data Source } \\
(3)\end{array}$ & $\begin{array}{l}\text { Price Deflator } \\
\text { (4) }\end{array}$ \\
\hline \multicolumn{4}{|l|}{ 1. Computerized Information } \\
\hline \multicolumn{4}{|c|}{ 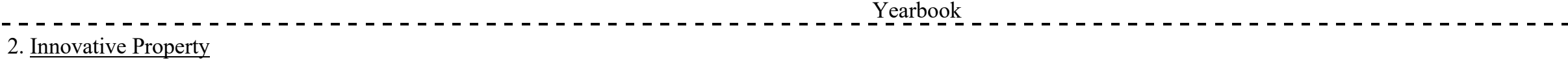 } \\
\hline 2.1. Mineral Exploration and Evaluation & Direct expenditures & China Statistical Yearbook of Mining & GDP deflator \\
\hline 2.2. Scientific R\&D & Direct expenditures & $\begin{array}{l}\text { China Statistical Yearbook of Science } \\
\text { and Technology }\end{array}$ & GDP deflator \\
\hline 2.3. Entertainment and Artistic Originals & $\begin{array}{l}\text { Use } 1 / 4 \text { of the revenues from traditional } \\
\text { publication industries of books, } \\
\text { magazines and newspapers and } \\
\text { double it to include television, } \\
\text { movies, video, audio, and digital } \\
\text { press }\end{array}$ & China Journalism Yearbook & GDP deflator \\
\hline 2.4. Financial Products and Services & $\begin{array}{l}20 \% \text { of immediate expenditures of } \\
\text { financial industry }\end{array}$ & $\begin{array}{c}\text { China National Statistical Yearbook, } \\
\text { World Input-Output Database }\end{array}$ & GDP deflator \\
\hline \multicolumn{4}{|c|}{ 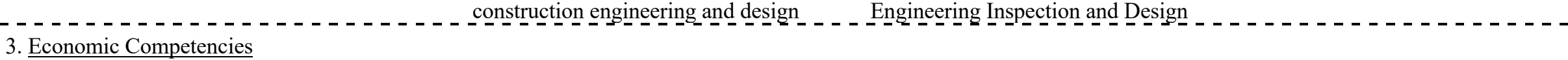 } \\
\hline 3.1. Advertising & $60 \%$ revenues from advertising industry & China Advertising Yearbook & Implicit wages and salaries deflator \\
\hline 3.2. Employer-provided Training & $2.5 \%$ management fees & $\begin{array}{l}\text { China Industrial Statistical Yearbook, } \\
\text { China National Statistical Yearbook }\end{array}$ & Implicit wages and salaries deflator \\
\hline 3.3. Organizational Structure & $5.0 \%$ management fees & $\begin{array}{l}\text { China Industrial Statistical Yearbook, } \\
\text { China National Statistical Yearbook }\end{array}$ & Implicit wages and salaries deflator \\
\hline
\end{tabular}

Notes: Discussions on the measurement of these variables are presented in $\mathrm{Li}$ and $\mathrm{Wu}$ (2017).

Source: Authors' own work.

Table 3.2 Descriptive Statistics of Intangible Capital

\begin{tabular}{lcccccccc}
\hline \hline Variable & Obs. & Mean & Median & S.D & Min & Max & Kurtosis \\
\hline RICI & 434 & 1 & 0.40 & 1.64 & 0.13 & 10.2 & 3.7 & 0.1 \\
$\log ($ RICI) & 434 & -0.6 & -0.90 & 0.96 & -2.03 & 2.3 & 0.99 \\
\hline Sour & & & & 3.56 & \\
\hline
\end{tabular}

Source: Authors' own computations. 
Figure 3.1 Spatial Distribution of China's Intangible Capital Intensity, 31 Provinces, in 2003 and 2016

\section{3}

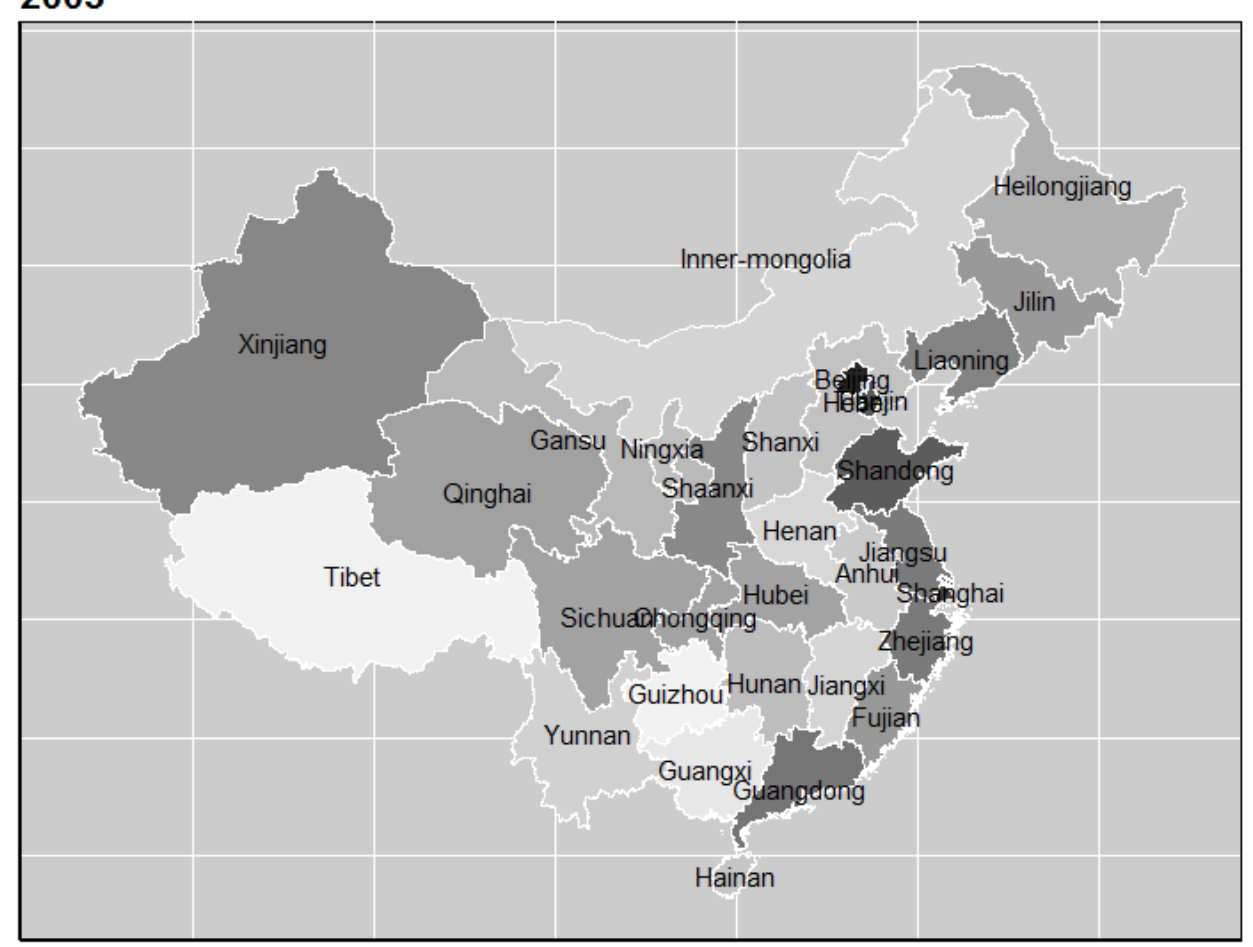

Log relative intangible capital

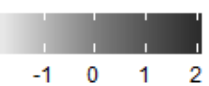

\section{6}

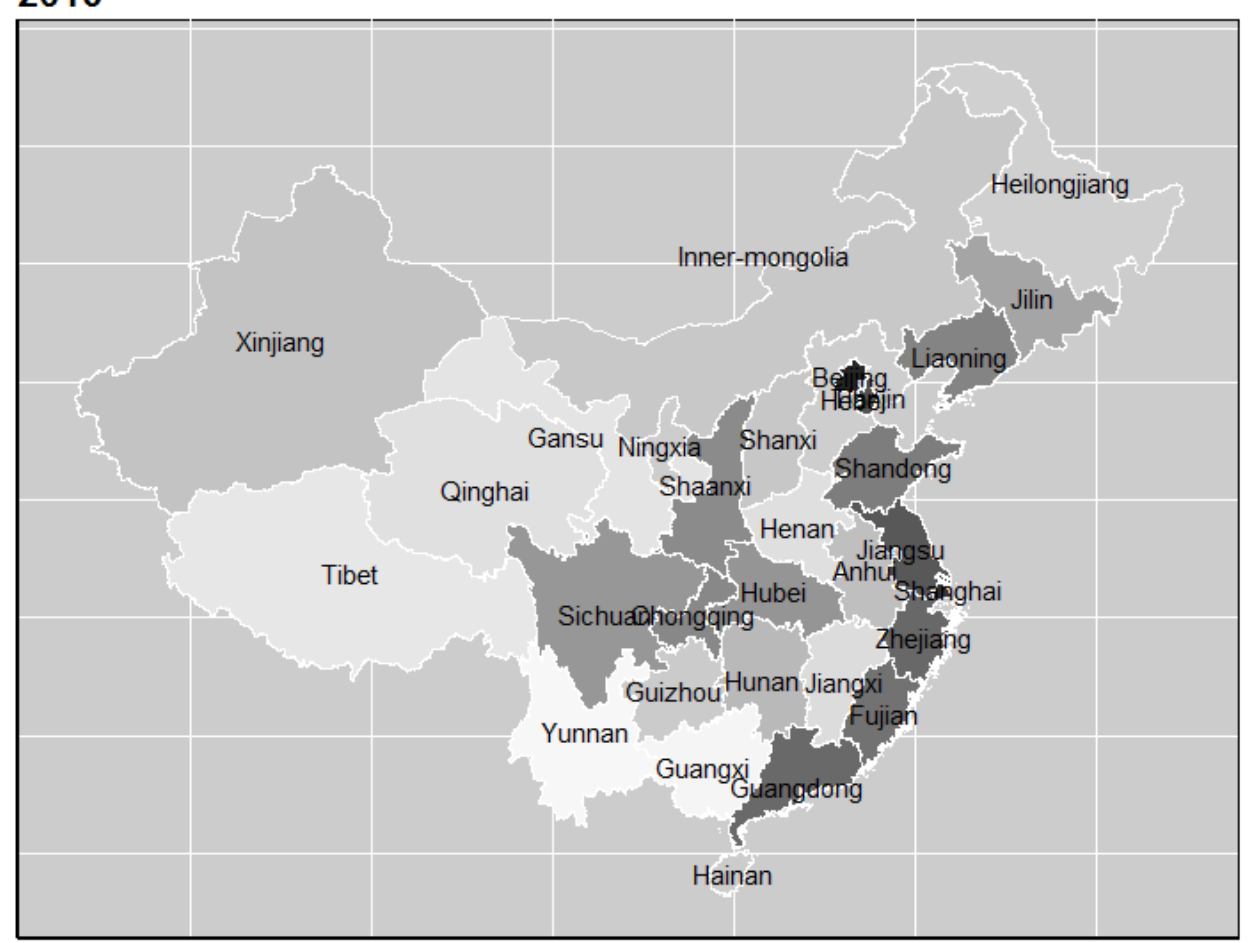

Log relative intangible capital

Notes: This figure maps the intensity of intangible capital investment in China for two selected years. Darker colors signify higher degrees of captial concentration. The underlying variable is $X_{i t}=\ln \left(\frac{y_{i t}}{\bar{y}_{t}}\right)=\ln y_{i t}-\ln \bar{y}_{t}$ where $y_{i t}$ is the constant price per capita investment (in RMB) for province $i$ in year $t$.

Source: Authors' own work. 
while more coastal regions accelerate. Overall, this pattern signifies impediments to the "catching up" process of the poor regions.

Next, we study this spatial distribution in a more formal fashion, by introducing a kernel function of the form:

$$
f(x)=\frac{1}{N h} \sum_{i=1}^{N} K\left(\frac{x-X_{i}}{h}\right),
$$

where $\mathrm{K}($.$) denotes the Epanechnikov function, \mathrm{N}$ is the number of regions, $\mathrm{X}_{\mathrm{i}}$ is the logarithmic RICI of province $\mathrm{i}$, and $\mathrm{h}$ is the selected bandwidth (also called "window width" or "smoothing parameter"). With a fixed bandwidth, an under (over)-smoothing density estimation bias may occur where there are too few (too many) observations (Silverman, 1986). To alleviate this problem, an adaptive kernel approach that allows bandwidths to vary (Abramson, 1982) is adopted. In this paper, we use the standard estimator proposed by Silverman (1986):

$$
f(x)=\frac{1}{\sum_{i=1}^{n} w_{i}} \sum_{i=1}^{n} \frac{w_{i}}{h_{i}} K\left(\frac{x-X_{i}}{h}\right),
$$

where $w_{i}$ is the weight associated with data point $i, h_{i}$ is the flexible bandwidth that is defined as $h_{i}=h \times \lambda_{i}$. The fixed bandwidth $h$, called as the pilot or "global" bandwidth, controls the overall degree of smoothing. $\lambda_{i}$ is a factor that stretches or shrinks the "local" bandwidths to adapt to the density of the data (Kerm, 2003). The estimation involves two steps. In the first step, we obtain h from a "naïve" estimate. In the second, the varying local bandwidth factor $\lambda_{i}$ is calculated as the square root of the geometric mean of the pilot density estimator over each point estimate.

Figure 3.2 presents the logarithmic RICI distributions in the representative years of 2003, 2009, and 2016. The peaks of the densities in selected years lie at around -1, implying that most regions in China exhibit a lower-than-average per capita intangible capital investment during 2003-2016. As can be seen, the unimodal shape of the distribution is virtually unchanged from 2003 to 2009, but a weak bi-model pattern emerges in 2016. Throughout the period $2003-2016$, there is an increase in the relative number of poor regions, which is in agreement with Figure 3.1. Furthermore, the global financial crisis may have played an important role in the divergence of RICI distribution into two "clubs" in 2016. We can clearly see that the right tail becomes "fatter" after crisis, suggesting a large developmental bias toward the richest regions.

Following Li and $\mathrm{Wu}$ (2017), out of the 31 regions, we group eleven into a "coastal" group and the rest into an "interior" group. ${ }^{9} \mathrm{We}$ found that the logarithmic RICI values in

\footnotetext{
${ }^{9}$ More details can be found in Section 5. The partition into coastal and interior (inland) regions is adopted to distinguish export-oriented/more developed areas from domestic market-oriented/less developed areas in
} 
Figure 3.2 Distribution of Intangible Capital in 2003, 2009 and 2016

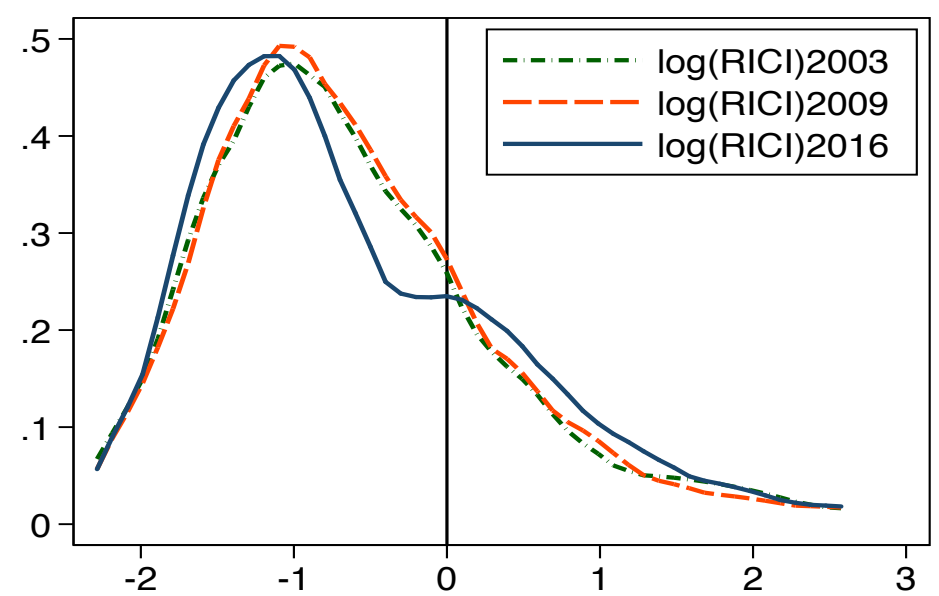

Notes: This Figure presents the un-weighted kernel density estimates of the distribution of intangible capital in China. Silverman (1986)'s adaptive bandwidth estimator is used.

Source: Authors' own estimates.

9/11 coastal regions are equal to or greater than the $75^{\text {th }}$ percentile. Shanghai and Beijing, the two major economic hubs, lie above the $95^{\text {th }}$ and $99^{\text {th }}$ percentiles, respectively. ${ }^{10}$ But will intangible investment continue to be concentrated in these regions? What does the distribution look like in the long-run if the trend of unbalanced development continues? Will the laggards converge to the leaders in the future? These are questions we address in the next two sections.

\section{Methodology}

\section{Conventional analyses}

From a methodology viewpoint, economic convergence studies have progressed along several dimensions and approaches (see Islam, 2003 for an extensive survey). One early mainstream approach is the so-called $\beta$-type convergence method. The title of this approach stems from the traditional notation of the slope coefficient in the regression of growth rates on initial income levels. Assuming diminishing returns, poorer economies with a lower initial income level will grow faster compared with richer ones with similar saving rates, leading to a process of "catching-up", i.e. convergence (Barro and Sala-i-martin, 1992;

China. The division criteria are also based on economic, administrative, historical and cultural factors (see e.g. Chen and Fleisher, 1996; Hao, 2008 and Ying, 2003).

${ }^{10}$ As discussed in Section 1, the clustering of intangible capital may be a manifestation of the effect of external economies of scale, i.e., initially labour-abundant coastal regions are fertile grounds for the facilitation of interactions among people, firms and institutions, leading to knowledge-based intangibles to be congregated (Faggian \& Mccann, 2009). Knowledge spill-overs are more frequent where people and firms learn by doing and observing their peers (Howells, 2002; Lever, 2002; Storper and Venables, 2004). As a result, business and employers prefer to locate in diverse, growing regions (coastal regions) to enjoy knowledge spill-overs, synergies and network effects (Meijers et al., 2016; Puga, 2010), this process, in turn, keeps stimulating and attracting even more intangible investment. 
Mankiw et al., 1992). It follows that a significant negative correlation (i.e. negative $\beta$ ) is expected between the initial income level and the subsequent growth rates, and is taken as evidence of convergence hypothesis. Based on the concept of $\beta$-type convergence, a vast body of empirical research has emerged involving China (to name only a few, Lau, 2010; Pedroni and Yao, 2006; Westerlund et al., 2010, Chen and Fleisher, 1996; Gries and Redlin, 2009; Hao, 2008 and Weeks and Yao, 2003). However, no research consensus has been reached. Different conclusions were generated by analysing different time periods and controlling for other different sets of explanatory variables.

One of the main criticisms of this approach is that the nature of convergence is a complex, dynamic evolution of both income levels and growth rates, which cannot be captured by a simple catch-all measure such as a negative $\beta$ (Johnson and Papageorgiou, 2018). In other words, a negative $\beta$ in the regression does not necessarily imply a reduction in the dispersion; hence it is a necessary but not sufficient condition for convergence. ${ }^{11}$ This criticism then motivates the concept of $\sigma$-type convergence, which, instead of looking at the slope coefficient, studies the standard deviation (denoted as $\sigma$ ) of the income distribution. A large strand of empirical studies presents $\sigma$ - convergence analyses in China context (Chen and Fleisher, 1996; Duan, 2008; Raiser, 1998; Zhou and Zou, 2010, among others). However, like their predecessors, $\sigma$-type convergence studies provide only one summary statistic of the distribution of interest, which cannot fully capture the complexity of the underlying distribution dynamics (for example changes from uni-modality to multimodality as of the case in Figure 3.2) .

\section{Dynamic Distribution Approaches}

Via a series of seminal papers, a non-parametric distribution analysis is introduced by Danny Quah to study economic convergence (see e.g. Quah, 1993a, 1996a, 1996b, 1997). This is in essence a data-driven approach and does not impose any prerequisite assumption or restriction on the distribution function. Distinct from analysing single summary statistics, this approach focuses on the shape of the entire distribution and its dynamics, and thus overcomes the limitation of both $\beta$ - and $\sigma$-type convergence studies as described above (Islam, 2003). This approach can be further divided into the discrete Markov chain and

\footnotetext{
${ }^{11}$ Some advocates for this line of criticism attribute this error to the classical Galton fallacy (see e.g. Friedman, 1992 and Quah, 1993b). The origin of this fallacy dates back to the studies by Charles Darwin's cousin Sir Francis Galton, who studied the regression towards the mean for human heights. Specifically, he discovered a "paradox": The sons of tall fathers tend to reverse towards a pool of mediocrity along with the sons of everyone else, yet male height dispersion does not fall overtime. Quah (1993b) shows that a given cross-sectional distribution that dynamically evolves is not inconsistent with arbitrary signs of the initial level regression coefficients (i.e. $\beta$ ). Therefore, a $\beta$-type convergence analysis is insufficient for a direct inference of convergence or divergence.
} 
stochastic kernel approaches. A major disadvantage of the discrete Markov chain method is that the demarcation of discrete states (to which each region fall into at any point in time) must be associated with an arbitrary selection of grid values (see e.g. Cheong and $\mathrm{Wu}, 2018$ ). As an alternative to circumvent the demarcation problem, a stochastic kernel approach is applied in our paper. Specifically, let $\mathrm{f}_{\mathrm{t}}(\mathrm{x})$ be the distribution of a variable $\mathrm{x}$ at time $\mathrm{t}$, and let $f_{t+\tau}(z)$ denote the distribution of a variable $z$ at time $t+\tau$. For our purposes, $x$ refers to the current RICI level, while z refers to the $\tau$-period-ahead level. Suppose the evolution of the distribution is time invariant, and assume that the distribution at time $t+\tau$ depends solely on the distribution at time $t$, the dynamic evolution process of the distribution from time $t$ to $t+\tau$ is can be expressed via the following differential equation:

$$
f_{t+\tau}(z)=\int_{0}^{\infty} g_{\tau}(z \mid x) f_{t}(x) d x,
$$

where $g_{\tau}(\mathrm{z} \mid \mathrm{x})$ is the conditional transition probability kernel that maps the distribution at time $\mathrm{t}$ to that at $\mathrm{t}+\tau$.

Since it is a density function, the integration of $g_{\tau}(z \mid x)$ over $z$ is unity (Johnson, 2005), that is, $\int_{0}^{\infty} g_{\tau}(z \mid x) d z=1$. To compute $g_{\tau}(z \mid x)$, we first derive the bivariate jointdensity :

$$
\mathrm{f}_{\mathrm{t}, \mathrm{t}+\tau}(\mathrm{x}, \mathrm{z})=\frac{1}{\mathrm{nh}_{\mathrm{z}} \mathrm{h}_{\mathrm{x}}} \sum_{\mathrm{i}=1}^{\mathrm{n}} \mathrm{K}\left(\frac{\mathrm{z}-\mathrm{z}_{\mathrm{i}}}{\mathrm{h}_{\mathrm{z}}}, \frac{\mathrm{x}-\mathrm{X}_{\mathrm{i}}}{\mathrm{h}_{\mathrm{x}}}\right),
$$

where $\mathrm{K}($.$) denotes the Epanechnikov function, \mathrm{n}$ is the number of observations, and $\mathrm{X}_{\mathrm{i}}$ and $\mathrm{Z}_{\mathrm{i}}$ denote the logarithmic RICI of province $\mathrm{i}$ at time $\mathrm{t}$ and $t+\tau$, respectively. $h_{x}$ and $h_{z}$ are the selected bandwidths for $\mathrm{x}$ and $\mathrm{z}$. Similar to the case of univariate density estimates, we mitigate under/over smoothing biases using the two-step adaptive kernel method of Silverman (1986). Due to restrictive sample sizes, annual transition probability estimators are used in order to obtain more reliable results, as suggested by Quah (2001). ${ }^{12}$ Then the transition probability kernel density can be computed as:

$$
\mathrm{g}_{\tau}(\mathrm{z} \mid \mathrm{x})=\frac{\mathrm{f}_{\mathrm{t}, \mathrm{t}+\tau}(\mathrm{x}, \mathrm{z})}{\mathrm{f}_{\mathrm{t}}(\mathrm{x})}
$$

where $f_{t}(x)$ is the marginal kernel density of $x$ [see Equation (3.1)]. Finally, given the timeinvariance of $g_{\tau}(z \mid x)$, the current distribution will evolve into a "steady-state" when $\tau$ goes to infinity. This "ergodic" distribution can be expressed via: ${ }^{13}$

$$
f_{\infty}(z)=\int_{0}^{\infty} g_{\tau}(z \mid x) f_{\infty}(x) d x
$$

\footnotetext{
12 The primary results do not change substantially when we instead use 3-year and 5-year transitions. These results are reported in the appendix. Longer horizons allow for greater mobility of the regions, but also reduce the number of observations.

${ }^{13}$ We solve for the ergodic distribution following the procedures outlined in Johnson (2005) and Juessen (2009).
} 


\section{The Augmented Mobility Probability Plot}

In addition to the above functions, we adopt another, newly developed tool in transition dynamics literature, namely, the mobility probability plot (MPP) proposed by Cheong and $\mathrm{Wu}$ (2014). Compared with traditional tools such as the kernel density plot, the contour plot, and the ergodic density plot, the MPP offers both a more direct interpretation and a broad overview of the results. Specifically, for each level of RICI at time t, the net probability of moving up to higher RICI levels is defined as the sum of the probabilities of moving up in the future distribution minus the sum of the probabilities of moving down. The MPP is measured in percentage and can be computed as:

$$
p(x)=\int_{x}^{\infty} g_{\tau}(z \mid x) d z-\int_{0}^{x} g_{\tau}(z \mid x) d z .
$$

However, the MPP in its current form is not without flaws. It is, in essence, a nonparametric point estimate, and does not offer much in term of how certain we are about whether our estimate of transition probability is statistically different from zero, that is, from immobility. It follows that hypothesis testing is infeasible in this case. To alleviate this concern, we propose our own novel augmentation of the MPP method, a simple bootstrap confidence interval (hereafter CI) for the estimated probabilities. To construct this CI, we follow a five-step simulation procedure:

1. Randomly draw with replacements from the actual sample of region-year $n=N \times T$ RICI values $(\mathrm{N}=31, \mathrm{~T}=13)$. Denoted this series as $\mathrm{x}_{\mathrm{s}}$. This series can be considered as one realization of the underlying data generating process at time $t$;

2. Locate the one-period ahead values of $\mathrm{x}_{\mathrm{s}}$, then stack them into a new series denoted as $\mathrm{z}_{\mathrm{S}}$. This is the simulated series at time $\mathrm{t}+1$;

3. Using $\mathrm{x}_{\mathrm{s}}$ and $\mathrm{x}_{\mathrm{z}}$ as inputs, re-estimate the joint density $\left[\mathrm{f}_{\mathrm{t}, \mathrm{t}+\tau}\left(\mathrm{x}_{\mathrm{s}}, \mathrm{z}_{\mathrm{s}}\right)\right]$ and conditional transition density $\left[\mathrm{g}_{\tau}\left(\mathrm{z}_{\mathrm{s}} \mid \mathrm{x}_{\mathrm{s}}\right)\right]$ via Equations (4.2) and (4.3);

4. Re-estimate the mobility probabilities $\left[\mathrm{p}\left(\mathrm{x}_{\mathrm{s}}\right)\right]$ using Equation (4.5).

5. Repeat steps one to four 10,000 times. Then, record the 2.5 percentile and 97.5 percentile of the 10,000 simulated mobility probabilities. These thresholds are the lower and upper bounds of the $95 \%$ confidence interval for our original estimates of mobility probabilities.

Arguably, with the constructed CI, we are able to draw conclusions on the likelihood of movements for regions at different RICI levels with stronger confidence than any previous studies. The wider the CI, the more uncertainty we will be regarding the RICI transition probabilities. 


\section{Results}

\section{Full Sample Dynamics}

Panel A of Figure 5.1 displays a three-dimensional (hereafter 3D) distribution of the annual transition probability of log RICI across all Chinese regions during 2003-2016. It can be interpreted as a posterior probability distribution at time $t+1$, given a specific distribution at time $t$. Imagine a line parallel to the $t+1$ axis at a chosen point on the $t$ axis. The intersection of a vertical plane with the base coincides to this line and the threedimensional surface will give us the density plot of the logarithmic RICI at $t+1$. A more intuitive perspective can be obtained from the corresponding density contour map, which is embedded in the $\mathrm{t}-\mathrm{t}+1$ plane in panel A, and plotted separately in panel B. It offers a "birdeye" view of the 3D surface, and the interpretation is straightforward. The spread of contour lines implies that intangible investment is widely dispersed across Chinese regions in the last two decades. The probability mass concentrates along the 45-degree line indicates low regional mobility: Provinces that are more intangible-intensive in previous year tend to sustain their advantages in the following year. ${ }^{14}$ Consistent with the $3 \mathrm{D}$ plot, two peaks can be seen clearly from the contour map, which indicates that regions tend to cluster into two groups. The higher peak is at -1.2 and the lower is at -0.4 , respectively, implying that the intangible investment intensity in most Chinese regions remains lower than the national average.

It is, however, somewhat difficult to determine where most of the probability mass lies by observing either the 3D plot or the contour (see e.g. Cheong and $\mathrm{Wu}, 2014$ ), prompting us to use the MPP that shows the net probabilities of moving upwards (i.e. the probability of increasing capital intensity). This is shown in panel C of Figure 5.1. In terms of point estimates, a positive net probability is observed for provinces with current intensity smaller than -1.3 and in the interval $[-0.8,-0.5]$. The majority of provinces, however, exhibit a net negative mobility probability, that is, their level of intangible capital tends to be reduced in the future. This finding is strengthened with the addition of the bootstrapped CI. It can be seen that upward mobility probability is only significant for very poor regions (values close to -2$)$. Note that the curves of actual estimate and both CI bounds start at 1 and end at -1 by construction (from left to right), i.e. probability of moving up (down) is $100 \%$ for the poorest (richest) region, hence there is no uncertainty at these extreme points. We can also see that uncertainty tend to increase when regions move

\footnotetext{
${ }^{14}$ If instead we observe a probability mass lying above the diagonal line in regions with below-average RICIs, and/or below the diagonal line in regions which have above-average RICIs, then a convergence is feasible: Poor/rich regions (in terms of capital intensity) will grow faster/slower in the future.
} 
Figure 5.1 Annual Transition Dynamics of Intangible Capital, 31 Provinces, 2003-2016

A. Conditional Probability Kernel

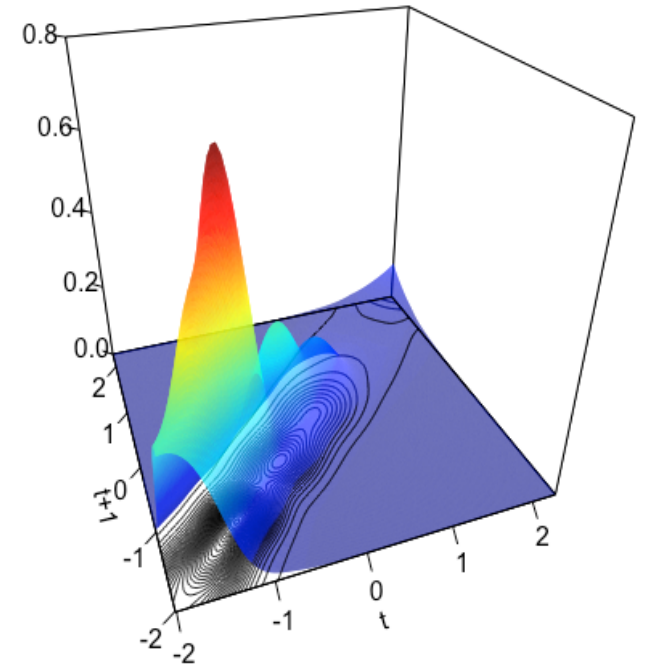

C. Mobility Probability Plot

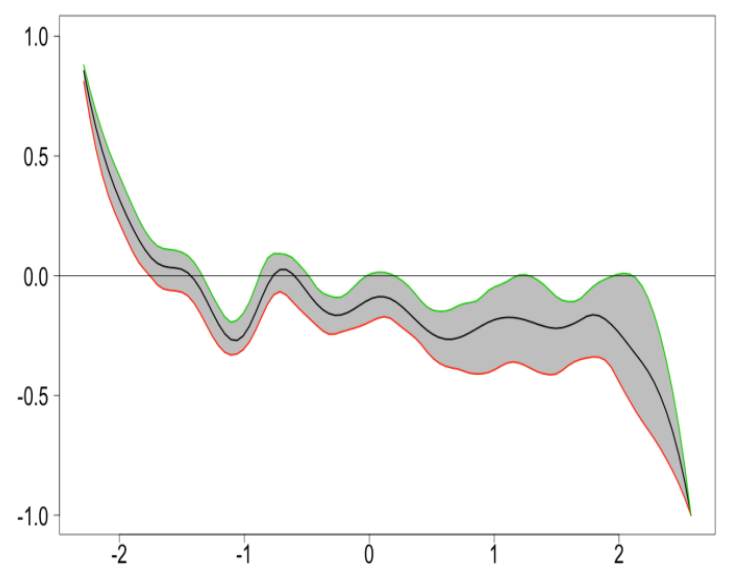

B. Contour of Conditional Probability Kernel

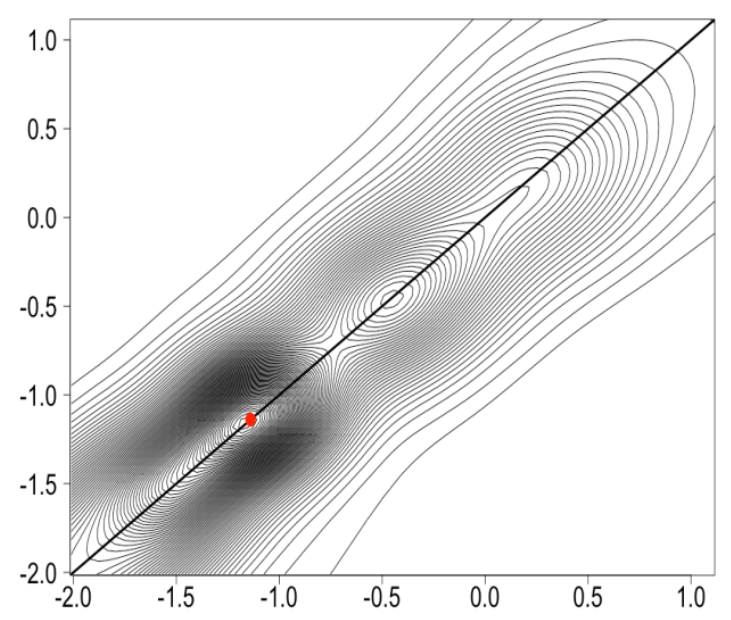

D. Ergodic Density Distribution

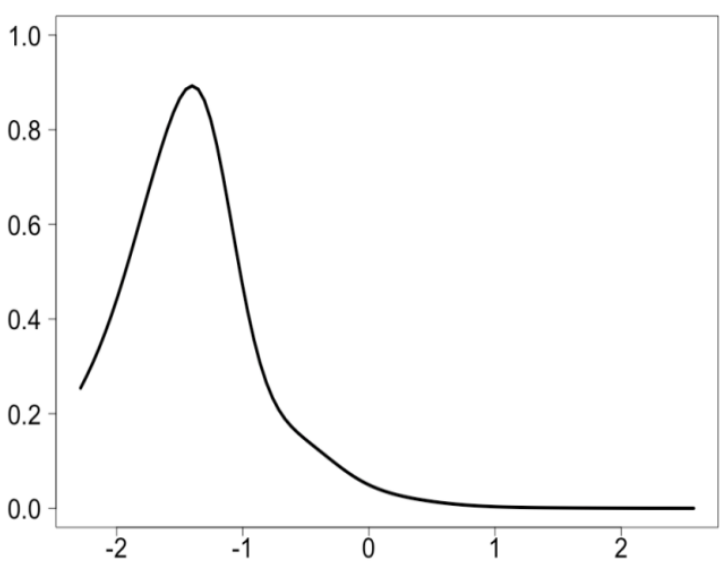

Notes: In panel B, and in corresponding panels in subsequent figures, the red dot indicates the highest peak of the conditional transition kernel. In Panel C, bootstrap confidence interval is constructed at $95 \%$ level of confidence. The number of bootstrap replications is 10,000 . The notes to the rest of the figures in this paper are similar to these notes.

Source: Authors' own works.

upwards. This is because estimation precision is reduced due to the decreasing number of observations. In short, the MPP plot reveals a lack of incentives to invest in intangible capital in Chinese provinces. Because of this, Chinese regions tend to converge to a lower-thanaverage intangible intensity in the long run.

This result is corroborated in the ergodic distribution plot shown in panel D. This plot presents the steady-state distribution based on the current transition path. The distribution's shape is unimodal with the highest peak at -1.2 , and the lower peak is now "absorbed" into the higher. It can be argued that our results are driven by a lack of mobility over the short time period of annual transitions. To alleviate this concern we extend our examination based on a three-year and a five-year transition probability path, of which 
results are reported in Appendix A $1 .{ }^{15}$ Increasing the length of the time steps does produce more mobility, but also reduces the numbers of transitions. In general the conclusions from these analyses are similar to those based on the annual transition analyses. For this reason, the rest of the paper will focus on annual transitions only.

\section{Intertemporal Dynamics}

To get better insights on the evolution of capital distribution over time, we examine the dynamics exhibited in two sub-periods, 2003-2009 and 2010-2016. Figure 5.2 illustrates the analogous plots to those in Figure 5.1 using observations partitioned into these subperiods. According to the 3D transition kernel plots (panel A), in the second period the peak clearly moves downward to a relatively lower level than that in the first. This implies that intangible-intensive regions in China tend to reduce their investment after outbreak of the global financial crisis (GFC). The shape of the distribution also changed considerably. Two obvious clusters are found during 2003-2009, but only one cluster is prominent during 20102016. The coordinates of the peaks in sub periods are highlighted in the contour maps (panel B). The highest peak moves from around -1.1 during 2003-2009 to about -1.3 during 20102016. As a result the most regions in China reach a lower level of intangible capital investment intensity after the crisis.

In both MPP plots (panel C), similar to that in Figure 5.1, the majority of regions tend to reach a lower future level of capital investment. For richer regions, negative net mobility is actually desirable if long-run convergence is to come. However, for poorer regions, especially those with RICI ranging from -1.5 to 0 , difficulty in moving upward hinders convergence. Additionally the CI gets wider for regions with high RICI levels, leading us to predict movements with less certainty. The inclusion of the horizontal zero line within CI at some low, middle and high RICI values indicate that we cannot reject the null hypothesis of immobility, or persistence, at these data points. This pattern is in agreement with the short-run concentration of the probability mass along the diagonal lines as shown in panels $\mathrm{A}$ and $\mathrm{B}$.

According to ergodic distributions in panel D, the RICI for most Chinese regions is far lower than the national mean (zero) in the steady-state distribution. In addition, the peak of the ergodic distribution is situated farther from zero in the post-crisis period than in the pre-crisis. It can be concluded that the under-development of intangible capital is exacerbated after the GFC.

\footnotetext{
15 The choices of horizons are in general aligned with typical business cycle literature and/or the "five-year plan" schedule often adopted by Chinese policy makers. China's five-year plans, also known collectively as the five-year guidelines (wunian jihua or guihua, in Chinese), is a series of crucial social and economic guidelines issued since 1953 to direct its political and economic transitions.
} 
Figure 5.2 Annual Transition Dynamics of Intangible Capital, Two Sub-Periods

A. Conditional Probability Kernel
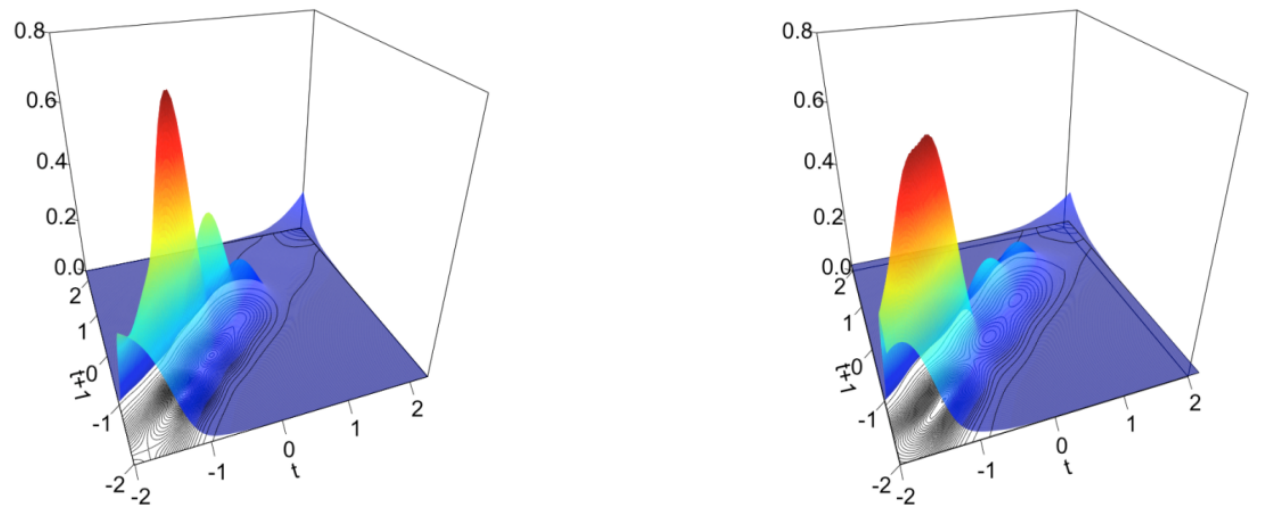

B. Contour of Conditional Probability Kernel
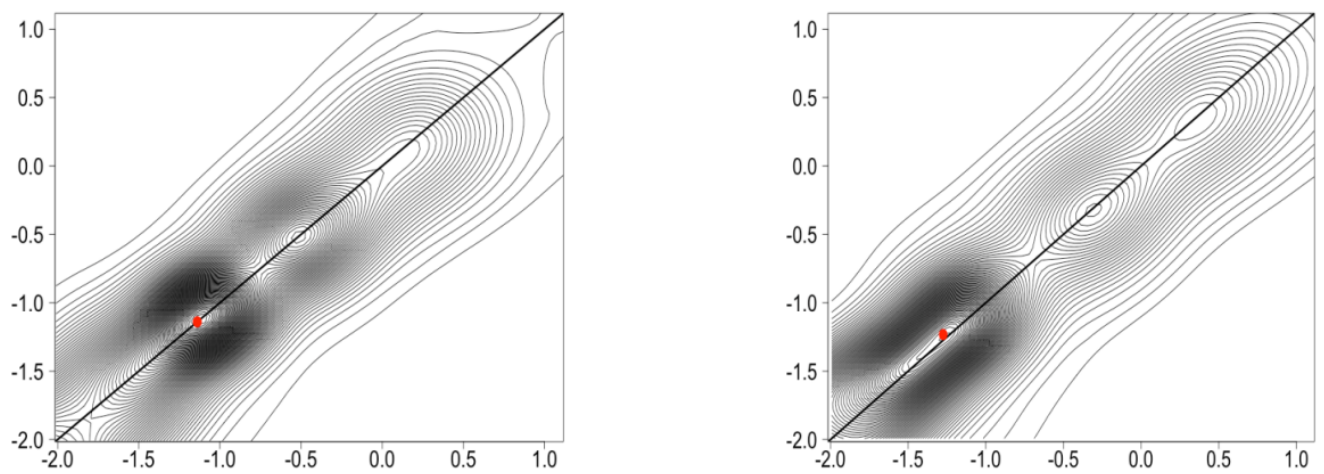

C. Mobility Probability Plot
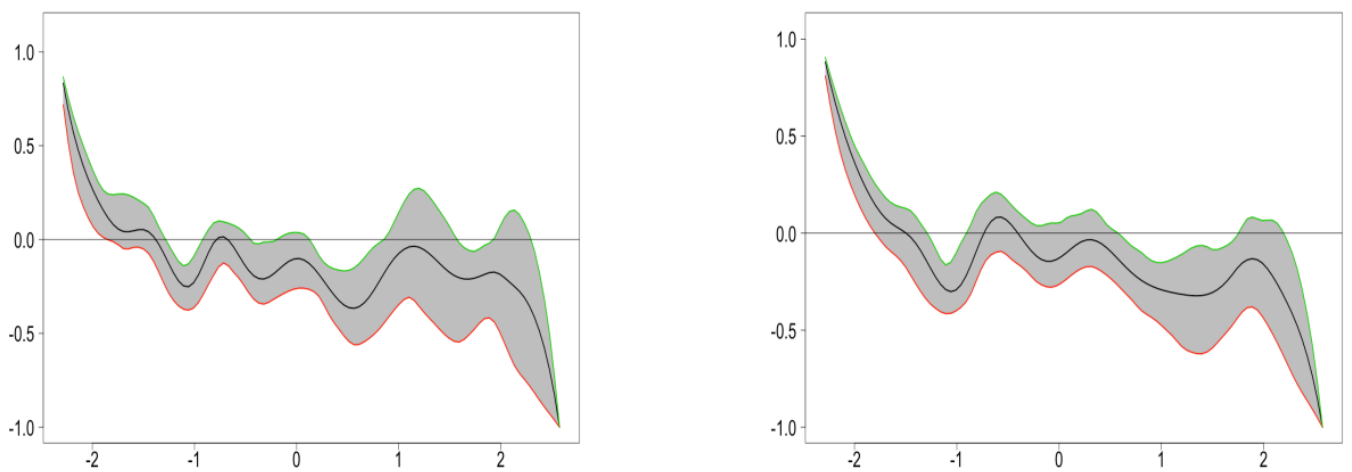

D. Ergodic Density Distribution
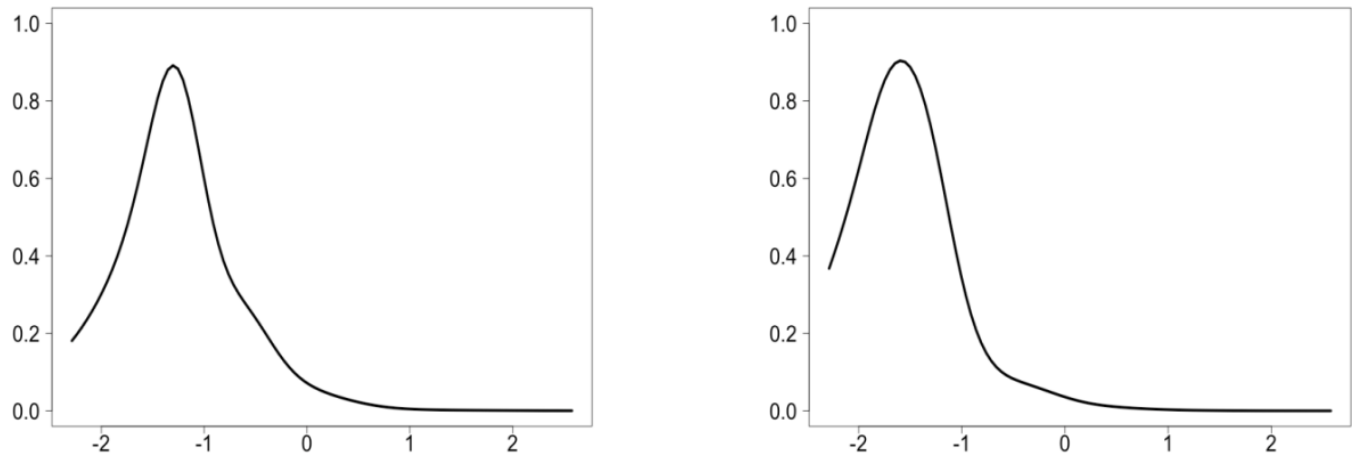

Notes: See notes to Figure 5.1. Source: Authors' own work. 


\section{Spatial Un-conditional Dynamics}

To understand regional disparity in China's intangible investment, we group the regions into two economic zones, namely, the coastal and the interior zones. Eleven coastal regions consist of Beijing, Tianjin, Liaoning, Hebei, Shanghai, Jiangsu, Zhejiang, Fujian, Shandong, Guangdong, and Hainan. Interior regions include the remaining twenty: Heilongjiang, Jilin, Inner-Mongolia, Shanxi, Anhui, Jiangxi, Henan, Hubei, Hunan, Guangxi, Sichuan, Chongqing, Guizhou, Yunnan, Shaanxi, Gansu, Qinghai, Ningxia, Xinjiang and Tibet. This division is consistent with previous studies and largely based on the economic and geographical clusters that characterize "clubs" of economic growth and development in China ( $\mathrm{Li}$ and $\mathrm{Wu}, 2017$ ). Considerable differences can be found in the $3 \mathrm{D}$ transition probability plot and the corresponding contours between these two economic zones. As can be seen from panels A and B of Figure 5.3, log RICI in most coastal regions are higher than the national mean, with the peak at around 0.3. In contrast, the peak of the interior regions' contour map is far below 0, lying around -1.2. Most interior regions have a level of RICI lower than the average. Panel B reveals that the largest probability mass of coastal regions is roughly located between [-0.5,1.0], while of interior regions is between [-1.5,-0.5]. In summary, there is a large gap in intangible capital investment between coastal and interior regions in China.

More importantly, the investment gap in China is predicted to be gradually widened. According to the left-hand side plot of panel C, the coastal regions' MPP curve lies above the horizontal zero line not only for very poor regions, but also in the [-0.5,0.5] range, which corresponds to where most of the probability mass concentrates. In words, provinces at which investment level is approximately 50 percent above or below the national mean tend to enjoy increasing investment. Furthermore, due to greater uncertainty associated with regions located at the right tail of the distribution, the CI implies that some far-ahead coastal regions can still sustain their intangible advantages. This can be seen by the upper bound of the CI crossing the horizontal zero line in the $[1.2,1.8]$ range. As a result, in the long-run the coastal regions will cluster to a higher-than-average investment peak, as illustrated by the steady-state unimodal distribution shown in the left-hand side plot of panel D. In stark contrast, MPP plot for interior regions indicates a strong trend of moving downward. Since there are only a few regions here belong to the right tail, compared with the coastal sample, we observe a much narrower CI towards the high values. There seem to be impediments for the convergence of interior provinces to reach the national mean. Additionally, "rich" regions in the interior sample will almost certainly become poorer in the long-run. Consequently, the ergodic distribution for this sample exhibits a very heavy left tail with a peak around -1.2. The main finding that China's coastal regions will out-perform interior regions in terms of intangible capital investments corroborates 
Figure 5.3 Annual Transition Dynamics of Intangible Capital, Two Economic Zones

\section{Coastal}

A. Conditional Probability Kernel

Interior

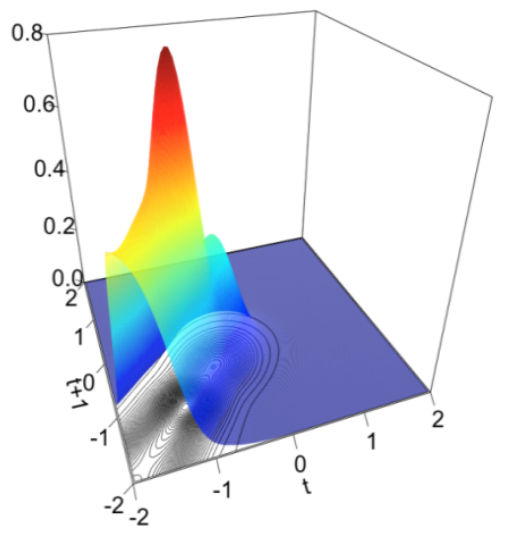

B. Contour of Conditional Probability Kernel
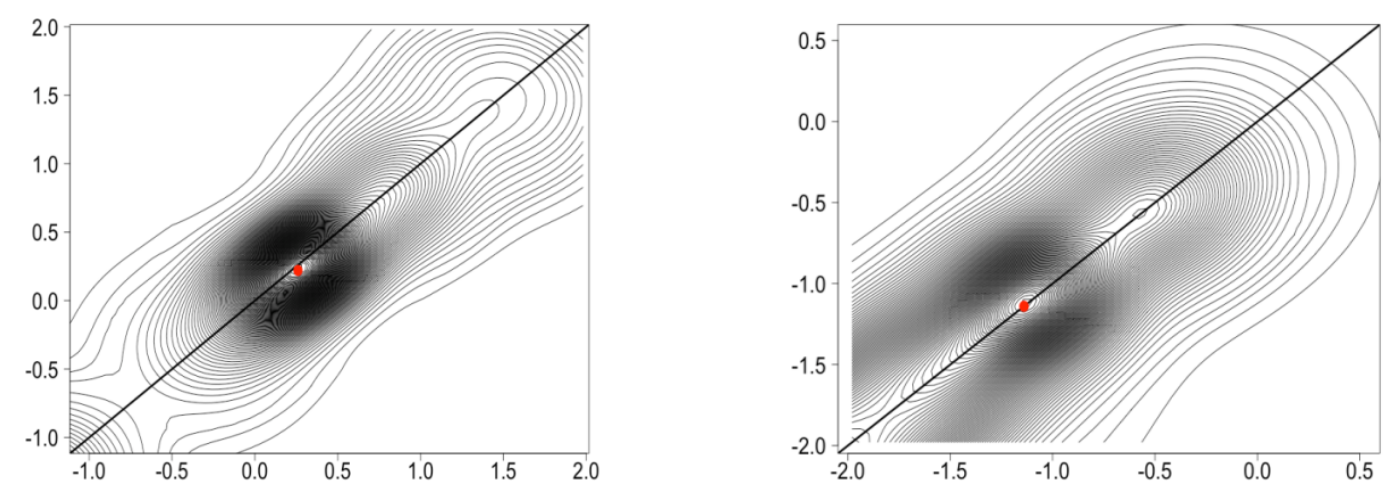

C. Mobility Probability Plot
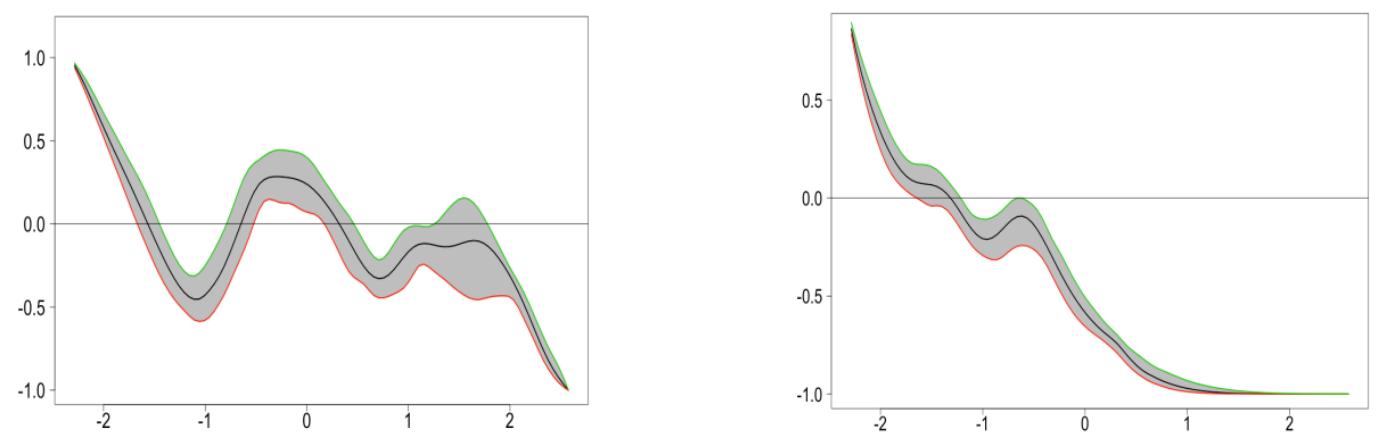

D. Ergodic Density Distribution
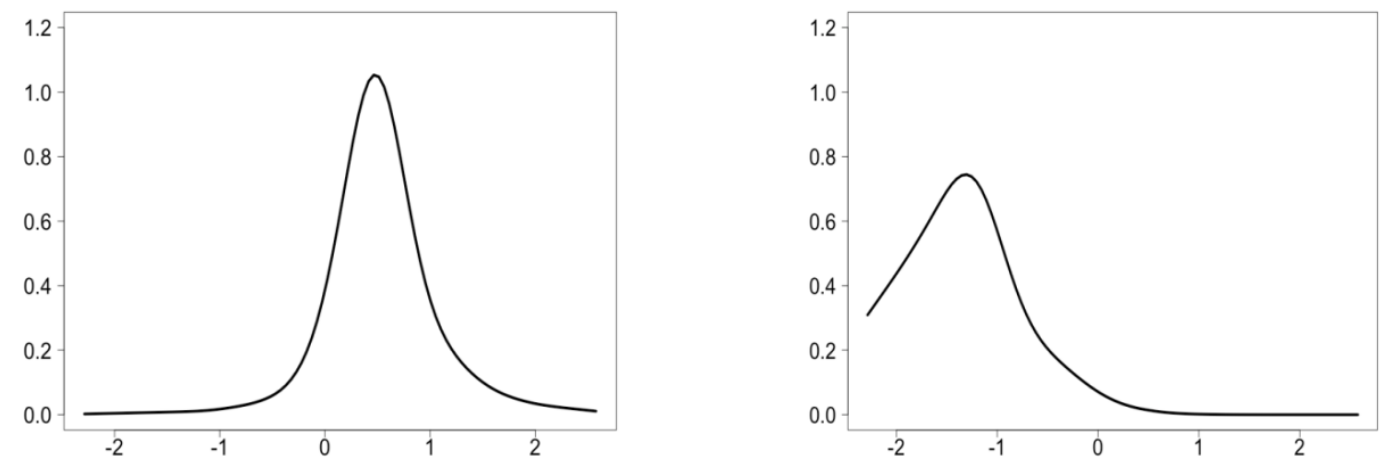

Notes: See notes to Figure 5.1. Source: Authors' own work. 
the viewpoints made by Haskel and Westlake (2018) in their recently published book "Capitalism without Capital". These authors argued that diverse, growing cities will become more attractive to businesses in a more intangible-oriented economy. This in turn increase industry congregation in specific places, raise housing prices, and finally push up the wealth inequality. ${ }^{16}$ In our context, coastal regions in China can capitalise on their historical advantages during the tangible-tointangible economic transition. ${ }^{17}$ The benefits of spill-overs and synergies in more-developed coastal regions induce business and talents to congregate to exploit and expand the already large cumulative network effects. In short, this newly developed "intangible economy of scale" mechanism is predicted to create a winner-takes-all setting and deteriorate China regional equality in the long run.

\section{Spatial Conditional Dynamics}

As mentioned above, intangible investment is perceived to involve knowledge spill-over effects. Geography is thus considered as one of the important determinants of the intangible investment distribution. Therefore, in the following discussion we re-examine the distribution with a geographical consideration. Specifically, we define conditional RICI as the ratio of log per capita intangible investment and the average of its geographical neighbours: $X_{i t}^{\prime}=\ln \left(\frac{y_{i t}}{\bar{y}_{N, t}}\right) \cdot \bar{y}_{N, t}$ denotes the mean of region i's neighbours (excluding the region itself). Neighbouring provinces are those sharing borders with the examined province. As the conditional distribution represents the impact of the conditioning factor on the distribution of the conditioned variable, the larger the distinction between unconditional and conditional distributions, the higher the explanatory power of the factor (Wu et al., 2018).

It can be seen from Figure 5.4 that the dynamic of the spatially conditional RICI is markedly different from that of the unconditional RICI (from Figure 5.1). Firstly, as shown by the transition kernel and contour plots (panel A and B), the probability mass of the conditional RICI lies in a range of $[-1,0.5]$ compared with that lies in $[-2,0]$ in the original transition plot. Different convergence clubs also occur, and the peak is close to the neighbours' average, which is zero in

\footnotetext{
${ }^{16}$ Haskel and Westlake (2018) emphasize the "four S" of intangible investment: Scalability, sunken-ness, spill-overs, and synergies. Specifically, intangible capital categories, relative to tangible types, are more likely to be scalable, meaning their costs are more likely to be sunk, and they are inclined to induce spill-overs and to exhibit synergies with each other. Because of the benefits from spill-overs (benefiting from intangible investments made by other firms and business) and synergies (combining different intangibles to produce unexpectedly large benefits), prosperous regions are more likely to thrive. The authors also linked the characteristics of intangibles with Glaeser's model of urban spill-overs and "Jacobs spill-overs" mentioned previously.

${ }^{17}$ Several empirical observations can be used to illustrate this point. Coastal regions currently host 75 percent of the biggest 500 companies (in terms of market capitalization) in 2010, a fifth of which are in Beijing. Headquarters of high-tech and retail giants are all located in coastal regions, for examples, Alibaba (Zhejiang), Baidu (Beijing), Tencent, HUAWEI and ZTE (Guangdong). In 2015, seven out of the top ten industrial clusters are in coastal regions, according to the Thousand Talents Program report (Duan, 2015). With respect to foreign direct investment (FDI), though the overall growth of investment tripled during 2005-2016, interior regions only have a share of less than $15 \%$ (RFIC, 2017).
} 
this case. In panel $\mathrm{C}$, there are only a few intersection points between the horizontal zero line and the conditional MPP estimate, meaning provinces move up and down with more or less equal probabilities. The results are quite robust with a narrow CI that has relatively stable width. As a result, the ergodic distribution resembles normality, with a peak located near zero. The finding that regional intangible investment levels in China are more likely to converge towards the mean of their geographical neighbours instead of the national average strengthens our proposition that investment distribution is a result of spill-over effects.

Figure 5.4 Annual Conditional Transition Dynamics, 31 Provinces, 2003-2016

A. Conditional Probability Kernel

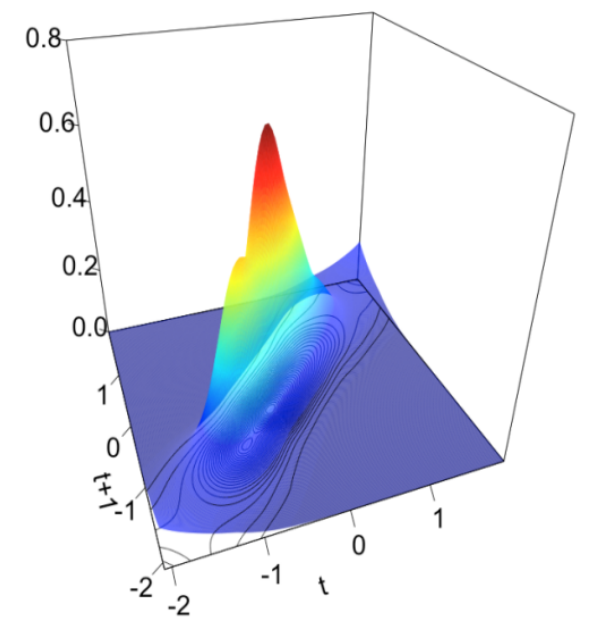

C. Mobility Probability Plot

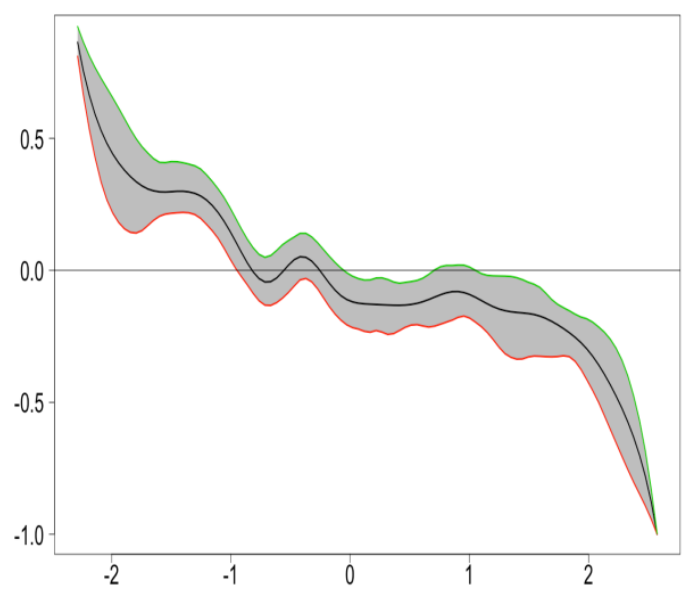

B. Contour of Conditional Probability Kernel

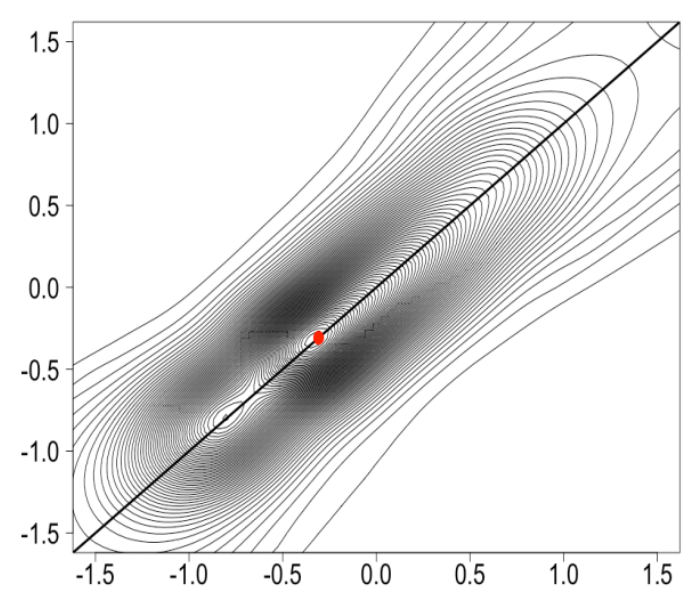

D. Ergodic Density Distribution

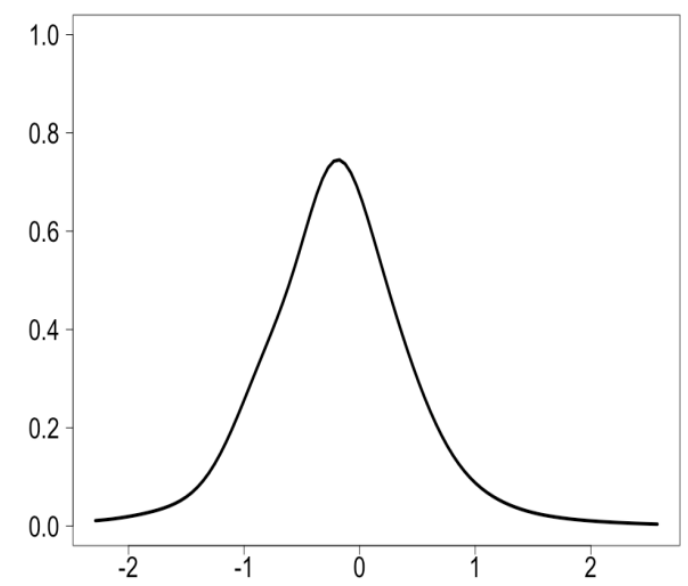

Notes: See notes to Figure 5.1. Source: Authors' own work.

As a robustness check, we repeat the above conditioning exercises for the two economic zones examined previously. If our hypothesis regarding spill-over effects is valid, this effect should be more profound for less geographically dispersed areas, i.e. those with lower physical costs of knowledge transfer. The results are presented in Figure A2 in the appendix, and we 
highlight the main findings here. In general, knowledge spill-overs affect intangible dynamic distributions in both main economic zones in China: Multimodality is found in the short-run distributions for both. Overall, the results echo those presented in the unconditional spatial distribution analyses. According to the conditional MPP plot of the coastal sample, richest regions (with logarithmic RICI values in the [1, 1.8] range) can still move up. More importantly, it appears that knowledge spill-overs tend to have a larger impact on regions with already high intangible capital intensity, than for less-developed regions. Again, the accumulation of intangible capital may lead to stronger economy of scales in these regions. ${ }^{18}$ A caveat for these experiments is that again, we observe wider CIs due to reduced sample sizes.

\section{Conclusions}

Arguably, a comprehensive interpretation of intangible investment across Chinese regions is of importance to understand China's regional economic growth and disparity. There has been, and will continue to be, a gradual shift from tangible to intangible economy across the globe, and China is not an exception to this rule. This transformation process is endogenously linked with the development of knowledge spill-over effects. In this paper, we emphasize that such effects are stronger in intangible-oriented regions, and therefore are crucial in understanding China's intangible capital distributions. Adopting a non-parametric transition dynamics approach, we examine the short-run transitional patterns as well as the long-term trends of per capita intangible capital investments in 31 Chinese provinces, cities and municipalities during the 13-year period 2003-2016. In addition to studying the full sample, we also examine sub-samples of different periods and economic zones.

The overall result indicates the underinvestment and unbalanced development characterize intangible investment in Chinese regions, which tend to manifest into convergence clusters. While there are only a few mega cities that are well endowed in intangible capital, most Chinese regions achieve below-average intangible capital intensity. In addition, long-term investment is projected to be low, leading to a steady-state distribution converging towards a level far lower than the national average.

The sub-period analysis is implemented by setting the global financial crisis as a cut-off. Considerable differences are found in pre- and post-crisis transition probabilities. In general, intangible capital investment is adversely affected by the crisis. Chinese regions, especially those with higher intangible capital intensity, tend to reduce investment in the post-crisis era. Investment clusters are not apparent in the second sub-periods. Compared with the pre-crisis transition path,

\footnotetext{
${ }^{18}$ Regarding interior regions, intersection values are greater in the conditional MPP plot compared with that in the unconditional one. The peak of the corresponding ergodic distribution also moves closer to zero. Similar to the coastal zone, it is easier for interior regions to converge to their neighbours' mean than to the national mean.
} 
most Chinese regions tend to converge to a lower RICI level based on the post-crisis transition path.

When we divide the regions into two economic zones, we find evidence supporting the idea that coastal regions dominant in intangible capital investment. In contrast, most interior regions lag behind, with investment levels far below the national average. Based on mobility probability plots and ergodic distribution plots, interior regions struggle to increase investment in the long run. Furthermore, as a robustness check of the importance of spatial factors, intangible investment distributions are re-estimated conditioning the average level of neighbouring provinces. The conditional RICI distribution dynamics change considerably, which highlights the role of knowledge spill-overs. We then find that it is easier for Chinese regions to converge to their neighbours' mean rather than the national mean investment.

Our findings suggest important implications for policy makers. First, intangible capital development is unbalanced in China. As an increasingly important economic power, it is crucial for China to strengthen its intangible infrastructure, especially in laggard interior regions. Beyond that, it also important to develop standards, rules and norm that underpin business' intangible investment (Haskel and Westlake, 2018). Technological synergies are crucial for an intangible economy while norms and standards safeguard such synergies. For instance, technological progress allows softwares to become more compatible overtime, but also more susceptible to illegal intellectual property (IP) right violations and privacy breaches. As such, well-designed regulations should help protect IP, facilitate balance between personal privacy and data collection and analyses. ${ }^{19}$

A second important finding is that a large gap is found in intangible capital investment between the coast and interior zones, and is predicted to be enlarging and lead to bimodal "convergence clubs" in the future. Spill-over effects play a crucial role in the distribution of intangible capital investment, and convergence is more likely to happen in adjacent regions first. With respect to this empirical regularity, the government may take advantage of spill-over effects by establishing intangible-intensive centres in middle-sized interior regions, reducing geographical barriers, and expand internet coverage. From the experiences of the special economic zone program, these clusters will benefit from a combination of intangible tax breaks, flexible financial supports, university-industry research collaborative joint-ventures, intangible capital subsidies, among other policies.

\footnotetext{
${ }^{19}$ An example of encouragement to intangible investment is the introduction of IP right protection. Thanks to the consistent effort from the government in enforcing this right, the numbers of computer software copyright registered increases by 83 percent in 2017 (SCIO, 2018). Other endeavours such as establishment of national funds for technology transfer, copyright transaction centres, and pilot commercialization centres (located in Xi' an and Zhuhai) have also supported the transfer and commercialization of intangible assets in recent years.
} 


\section{References}

Abramson, I. S. (1982). On Bandwidth Variation in Kernel Estimates-A Square Root Law. The Annals of Statistics, 10(4), 1217-1223.

Andersson, F. N. G., Edgerton, D. L., \& Opper, S. (2013). A Matter of Time: Revisiting Growth Convergence in China. World Development, 45, 239-251. https://doi.org/10.1016/j.worlddev.2012.12.013

Arrow, K. J. (1962). The Economic Implications of Learning by Doing. The Review of Economic Studies, 29(3), 155-173. Retrieved from http://www.jstor.org.ezproxy.unal.edu.co/stable/pdf/2295952.pdf

Baldwin, J. R., Gu, W., \& MacDonald, R. (2012). Intangible Capital and Productivity Growth in Canada. The Canadian Productivity Review, (15), 6-41. https://doi.org/10.2139/ssrn.2093526

Barnes, P., \& McClure, A. (2009). Investments in Intangible Assets and Australia's Productivity Growth. Productivity Commission. Canberra. Retrieved from https://ssrn.com/abstract=1616921

Barro, R. J., \& Sala-i-martin, X. (1992). Convergence. Journal of Political Economy, 100, 223-251.

Belhocine, N. (2009). Treating Intangible Inputs as Investment Goods : The Impact on Canadian GDP. International Monetary Fund.

Carlino, G. A. (2001). Knowledge Spillovers: Cities' Role in the New Economy. Business Review - Federal Reserve Bank of Philadelphia, 17-26.

Chen, J., \& Fleisher, B. M. (1996). Regional Income Inequality and Economic Growth in China. Journal of Comparative Economics, 22(2), 141-164. https://doi.org/10.1006/jcec.1996.0015

Cheong, T. S., \& Wu, Y. (2013). Regional Disparity, Transitional Dynamics and Convergence in China. Journal of Asian Economics, 29, 1-14. https://doi.org/10.1016/j.asieco.2013.08.007

Cheong, T. S., \& Wu, Y. (2014). The Impacts of Structural Transformation and Industrial Upgrading on Regional Inequality in China. China Economic Review, 31, 339-350. https://doi.org/10.1016/j.chieco.2014.09.007

Cheong, T. S., \& Wu, Y. (2018). Convergence and Transitional Dynamics of China's Industrial Output: A County-level Study using a New Framework of Distribution Dynamics Analysis. China Economic Review, 48, 125-138. https://doi.org/10.1016/j.chieco.2015.11.012

Corrado, C. A., Haskel, J., Jona-lasinio, C., \& Iommi, M. (2014). Intangibles and Industry Productivity Growth: Evidence from the EU. IARIW 33rd General Conference, 1-30. Retrieved from http://www.iariw.org/papers/2014/LasinioPaper.pdf

Corrado, C. A., Hulten, C. R., \& Sichel, D. (2009). Intangible Capital and U.S. Economic Growth. Review of Income and Wealth, 55(3), 661-685. https://doi.org/10.1111/j.1475-4991.2009.00343.x

Corrado, C. A., Hulten, C. R., \& Sichel, D. E. (2005). Measuring Capital and Technology: An Expanded Framework. In C. Carrodo, J. Haltiwanger, \& D. Sichel (Eds.), Measuring Capital in the New Economy (pp. 11-46). Washinton, D.C.: University Chicago Press.

Corrado, C. A., Hulten, C. R., \& Sichel, D. E. (2006). Intangible Capital and Economic Growth (NBER Working Paper No. 11948).

Duan, L. (2015). Young Scholar Thousand Plan in 2015. Medical Research \& Publication, 1(1), 14-15. https://doi.org/10.15894/j.cnki.cn11-3040/a.2015.04.005

Duan, P. (2008). Influence of China's Population Mobility on the Change of Regional Disparity since 1978. Zhongguo Renkou Ziyuan Yu Huan Jing/ China Population Resources and Environment, 18(5), 27 33. https://doi.org/10.1016/S1872-583X(09)60018-8

Dutz, M. A., Kannebley Jr., S., Scarpelli, M., \& Sharma, S. (2012). Measuring Intangible Assets in an Emerging Market Economy: An Application to Brazil. Policy Research Working Paper, WPS6142(July). Retrieved from http://documents.worldbank.org/curated/en/2012/07/16530073/measuring-intangible-assetsemerging-market-economy-application-brazil

Faggian, A., \& Mccann, P. (2009). Universities, Agglomerations and Graduate Human Capital Mobility. Tijdschrift Voor Economische En Sociale Geografie, 100(2), 210-223. https://doi.org/10.1111/j.1467-9663.2009.00530.x

Friedman, M. (1992). Do Old Fallacies Ever Die? Published by: American Economic Association Cornmunication. Journal of Economic Literature, 30(4), 2129-2132.

Fukao, K., Hamagata, S., Miyagawa, T., \& Tonogi, K. (2009). Intangible Investment in Japan: Measurement and Contribution to Economic Growth. Review of Income and Wealth, 55(3), 717-736.

Glaeser, E. (1999). Learning in Cities. Journal of Urban Economics, 46(2), 254-277. 
https://doi.org/10.1006/juec.1998.2121

Glaeser, E. (2012). Triumph of the City: How Our Greatest Invention Makes Us Richer, Smarter, Greener, Healthier, and Happier. Pan Macmillan.

Gries, T., \& Redlin, M. (2009). China's Provincial Disparities and the Determinants of Provincial Inequality. China's Three Decades of Economic Reforms, 5284(May), 113-132. https://doi.org/10.4324/9780203873885

Hao, R. (2008). Opening up, Market Reform, and Convergence Clubs in China. Asian Economic Journal, 22(2), 133-160. https://doi.org/10.1111/j.1467-8381.2008.00272.x

Haskel, J., \& Westlake, S. (2018). Capitalism without Capital. Princeton: Princeton University Press.

Herrerías, M. J., Orts, V., \& Tortosa-Ausina, E. (2011). Weighted Convergence and Regional Clusters across China. Papers in Regional Science, 90(4), 703-734. https://doi.org/10.1111/j.14355957.2010.00339.x

Howells, J. (2002). Tacit Knowledge, Innovation and Economic Geography. Urban Studies, 39(5-6), 871884. https://doi.org/10.1080/0042098022012835

Hulten, C. R., \& Hao, J. X. (2012). The Role Of Intangible Capital in the Transformation and Growth of the Chinese Economy (NBER Working Paper No. 18405). https://doi.org/10.3386/w18405

Islam, N. (2003). What have We Learnt from the Convergence Debate? Journal of Economic Surveys, 17(3), 309-362. https://doi.org/10.1111/1467-6419.00197

Johnson, P. A. (2005). A Continuous State Space Approach to "Convergence by Parts." Economics Letters, 86(3), 317-321. https://doi.org/10.1016/j.econlet.2004.06.023

Johnson, P., \& Papageorgiou, C. (2018). What Remains of Cross-Country Convergence. Journal of Economic Literature. https://doi.org/https://mpra.ub.uni-muenchen.de/89355/

Jona-Lasinio, C., Lommi, M., \& Roth, F. (2011). National Measures of Intangible Capital in EU27 and Norway. In Intangible Capital-Driver of Growth in Europe (pp. 20-62). Retrieved from http://innodrive.org/attachments/File/Intangible_Capital_Driver_of_Growth_in_Europe_Piekkola(e d).pdf

Juessen, F. (2009). A Distribution Dynamics Approach to Regional GDP Convergence in Unified Germany. Empirical Economics, 37, 627-652. https://doi.org/10.1055/s-0028-1128055

Kerm, P. Van. (2003). Adaptive Kernel Density Estimation. Stata Journal, 3(2), 148-156. https://doi.org/The Stata Journal

Krugman, P., Obstfeld, M., \& Melitz, M. J. (2018). International Trade: Theory and Policy. Pearson Education.

Kumar, S., \& Russell, R. R. (2002). Technological Change , Technological Catch-up , and Capital Deepening : Relative Contributions to Growth and Convergence. American Economic Review, 92(3), 527-548.

Lau, C. K. M. (2010). New Evidence about Regional Income Divergence in China. China Economic Review, 21(2), 293-309. https://doi.org/10.1016/j.chieco.2010.01.003

Lemoine, F., Poncet, S., \& Ünal, D. (2015). Spatial Rebalancing and Industrial Convergence in China. China Economic Review, 34, 39-63. https://doi.org/10.1016/j.chieco.2015.03.007

Lever, W. F. (2002). Correlating the Knowledge-base of Cities with Economic Growth. Urban Studies, 39(August 2001), 859-870. https://doi.org/10.1080/0042098022012834

Li, Q., \& Wu, Y. (2017). Intangible Capital in Chinese Regional Economies: Measurement and Analysis. China Economic Review. https://doi.org/10.1016/j.chieco.2017.07.002

Mankiw, N. G., Romer, D., \& Weil, D. N. (1992). A Contribution to the Empirics of Economic Growth. Quarterly Journal of Economics, 107, 407-437. https://doi.org/10.1016/j.jpolmod.2014.01.001

Meijers, E. J., Burger, M. J., \& Hoogerbrugge, M. M. (2016). Borrowing Size in Networks of Cities: City Size, Network Connectivity and Metropolitan Functions in Europe. Papers in Regional Science, 95(1), 181-198. https://doi.org/10.1111/pirs.12181

NBS. (2017). China National Bureau of Statistics.

Pedroni, P., \& Yao, J. Y. (2006). Regional Income Divergence in China. Journal of Asian Economics, 17(2), 294-315. https://doi.org/10.1016/j.asieco.2005.09.005

Puga, D. (2010). The Magnitude and Causes of Agglomeration Economies. Journal of Regional Science, 50(1), 203-219. https://doi.org/10.1111/j.1467-9787.2009.00657.x

Quah, D. (1993a). Empirical Cross-Section Dynamics in Economic Growth. European Economic Review, 37(December), 426-434.

Quah, D. (1993b). Galton' s Fallacy and Tests of the Convergence Hypothesis. Scandinavian Journal of Economics, 95(4), 427-443. 
Quah, D. (1996a). Aggregate and Regional Disaggregate Fluctuations. Empirical Economics, 21(1), 137159. https://doi.org/10.1007/978-3-642-61211-4_7

Quah, D. (1996b). Twin Peaks: Growth and Convergence in Models of Distribution Dynamics. The Economic Journal, 106(437), 1045-1055.

Quah, D. (1997). Empirics for Growth and Distribution: Stratification, Polarization, and Convergence Clubs. Journal of Economic Growth, 2(1), 27-59. https://doi.org/10.1023/a:1009781613339

Quah, D. (2001). Searching for Prosperity A Comment. Carnegie-Rochester Conference Series on Public Policy, 55(1), 305-319.

Raiser, M. (1998). Subsidising Inequality: Economic Reforms, Fiscal Transfers and Convergence across Chinese Provinces. Journal of Development Studies, 34(3), 1-26. https://doi.org/10.1080/00220389808422518

RFIC. (2017). Report on Foreign Investment in China. Ministry of Commerce of the People's Republic of China.

Romer, P. M. (1986). Increasing Returns and Long-run Growth. Journal of Political Economy, 94(5), $1002-1037$.

Rosenthal, S. S., \& Strange, W. C. (2004). Evidence on the Nature and Sources of Agglomeration Economies. Handbook of Regional and Urban Economics (Vol. 4). Elsevier Inc. https://doi.org/10.1016/S1574-0080(04)80006-3

Sakamoto, H., \& Islam, N. (2008). Convergence across Chinese Provinces: An Analysis using Markov Transition Matrix. China Economic Review, 19(1), 66-79. https://doi.org/10.1016/j.chieco.2006.07.002

SCIO. (2018). SCIO Briefing on Development of China's Intellectual Property Rights. Retrieved from http://english.scio.gov.cn/pressroom/2018-04/25/content 50960531_0.htm

Silverman, B. W. (1986). Density Estimation for Statistics and Data Analysis. ChapMan \& HALL/CRC. https://doi.org/10.2307/2347507

Storper, M., \& Venables, A. J. (2004). Buzz: Face-to-face Contact and the Urban Economy. Journal of Economic Geography, 4(4), 351-370. https://doi.org/10.1093/jnlecg/lbh027

Tian, K., Ni, H., \& Li, L. (2016). National Measures of Intangible Asset and Its Role in Growth of China Economy. China Industrial Economics, (3), 5-19.

van Ark, B., Hao, J. X., Corrado, C., \& Hulten, C. (2009). Measuring Intangible Capital and Its Contribution to Economic Growth in Europe. EIB Papers, 14(1), 62-93.

Weeks, M., \& Yao, J. Y. (2003). Provincial Conditional Income Convergence in China, 1953-1997: A Panel Data Approach. Econometric Reviews, 22(1), 59-77. https://doi.org/10.1081/ETC-120017974

Westerlund, J., Edgerton, D. L., \& Opper, S. (2010). Why is Chinese Provincial Output Diverging? Journal of Asian Economics, 21(4), 333-344. https://doi.org/10.1016/j.asieco.2010.03.007

World Bank. (2018). World Development Indicators. Retrieved from https://data.worldbank.org/

Wu, J., Wu, Y., Se Cheong, T., \& Yu, Y. (2018). Distribution Dynamics of Energy Intensity in Chinese Cities. Applied Energy, 211(October 2017), 875-889. https://doi.org/10.1016/j.apenergy.2017.10.097

Ying, L. G. (2003). Understanding China's Recent Growth Experience: A Spatial Econometric Perspective. Annals of Regional Science, 37(4), 613-628. https://doi.org/10.1007/s00168-003-0129-x

Zhou, H., \& Zou, W. (2010). Income Distribution Dynamics of Urban Residents: The Case of China (1995-2004). Frontiers of Economics in China, 5(1), 114-134. https://doi.org/10.1007/s11459-010-0006-3 


\section{APPENDIX}

Figure A1. Three-year and Five-year Transition Dynamics, 31 Provinces Three-year

A. Conditional Probability Kernel

Five-year

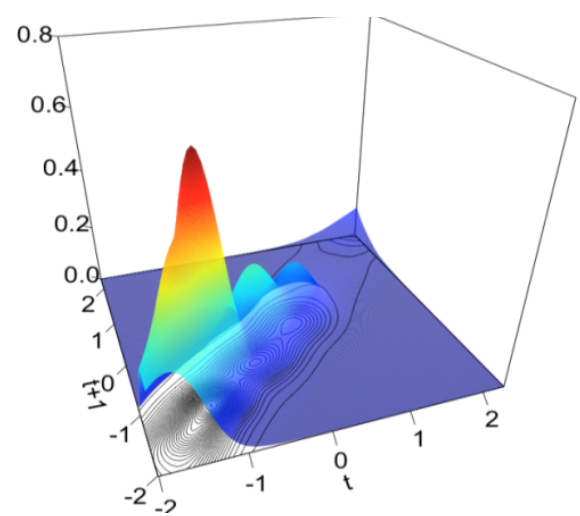

B. Contour of Conditional Probability Kernel
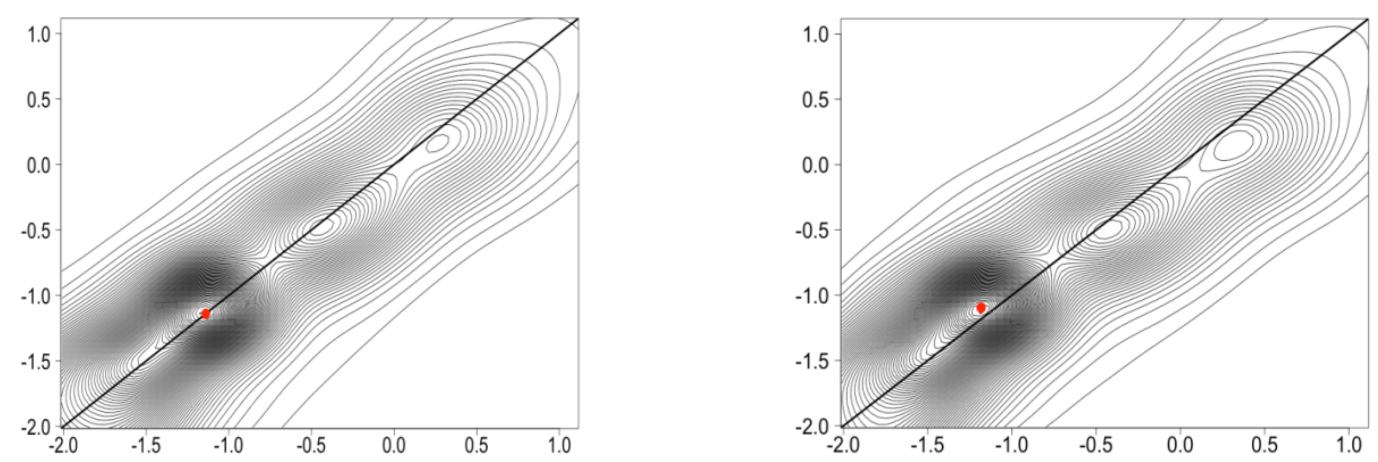

C. Mobility Probability Plot
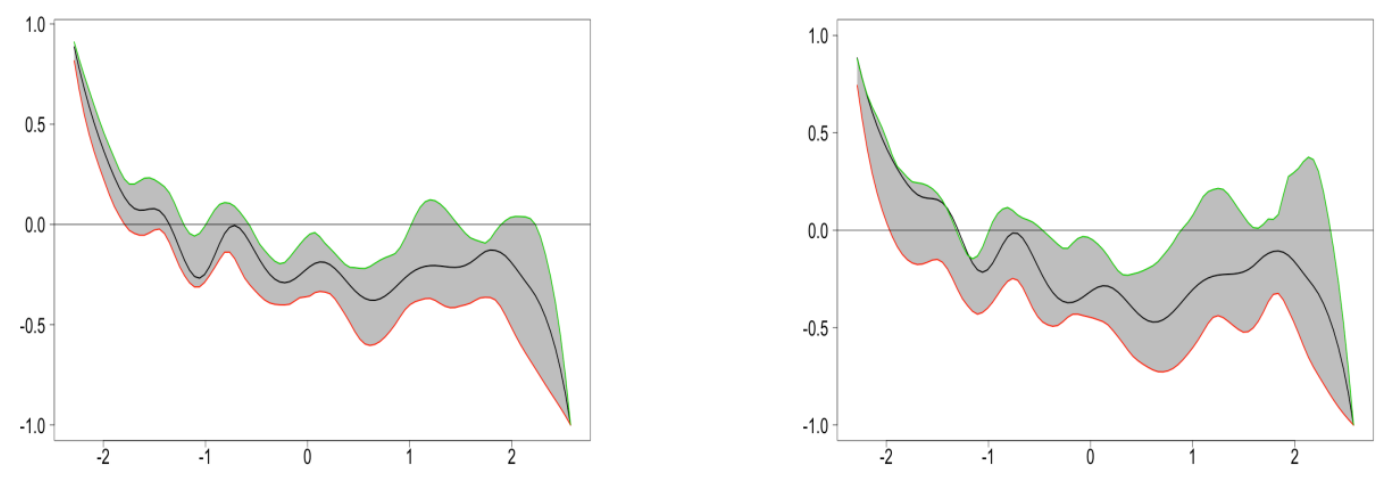

D. Ergodic Density Distribution
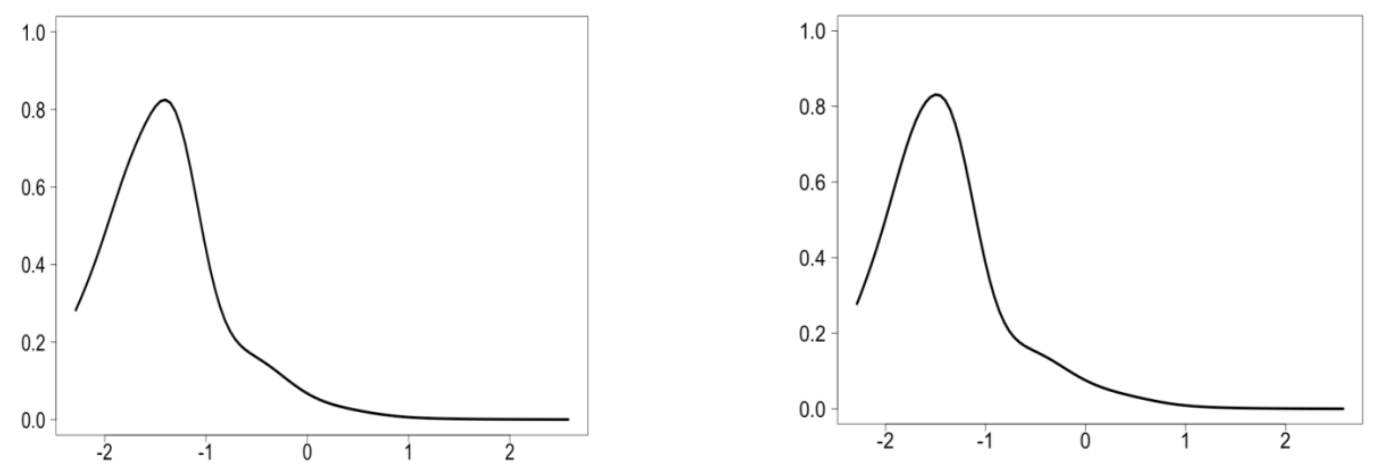

Notes: See notes to Figure 5.1. Source: Authors' own work. 
Figure A2. Annual Conditional Transition Dynamics, Coastal and Interior Regions Coastal

\section{A. Conditional Probability Kernel}

Interior

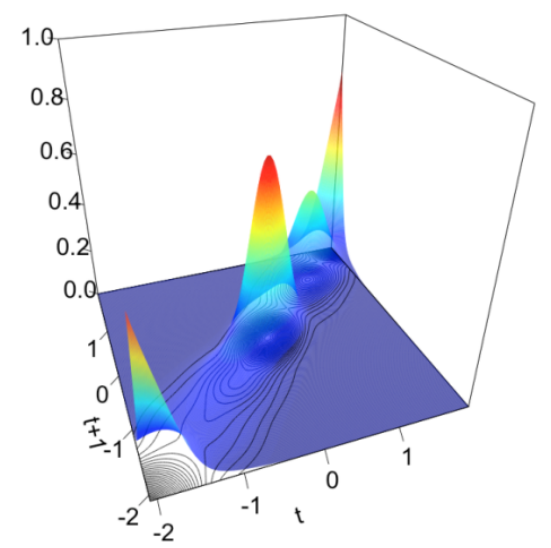

B. Contour of Conditional Probability Kernel
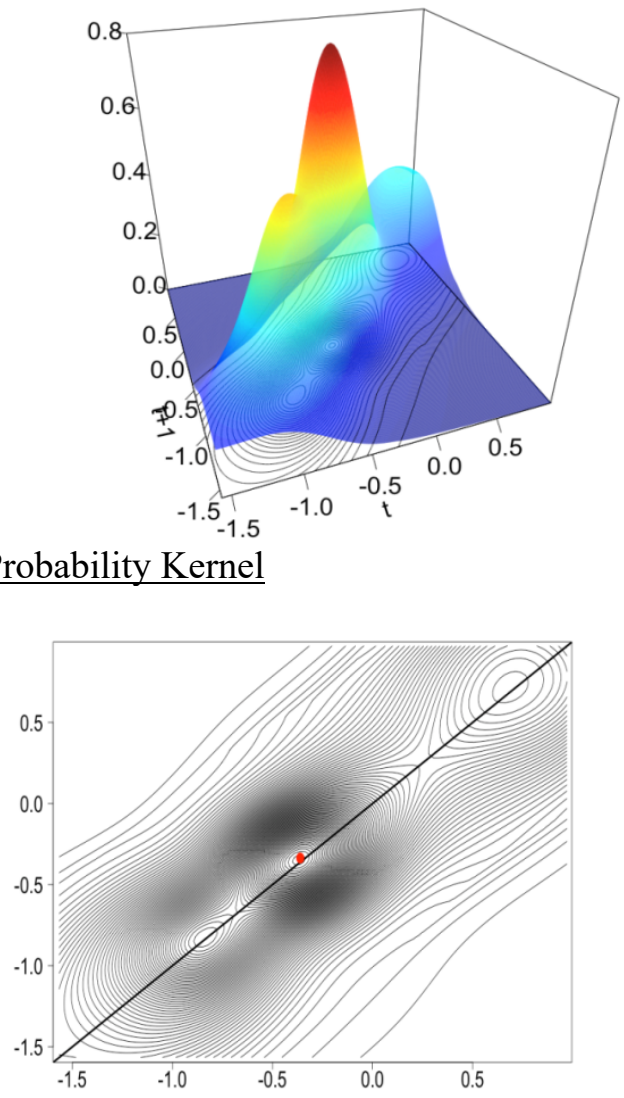

C. Mobility Probability Plot
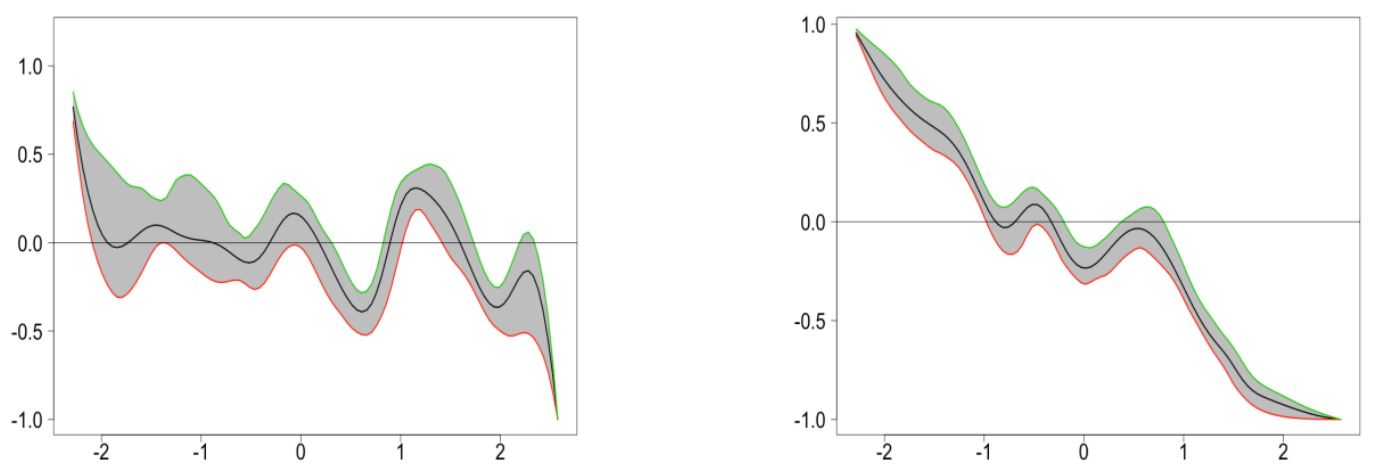

D. Ergodic Density Distribution
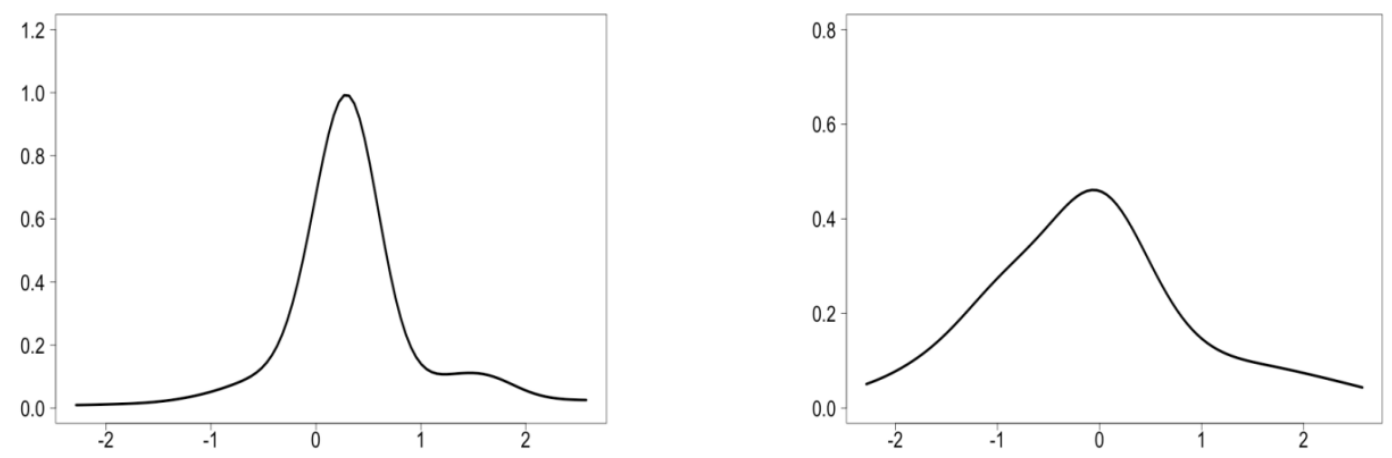

Notes: See notes to Figure 5.1. Source: Authors' own work. 
Editor, UWA Economics Discussion Papers:

Sam Hak Kan Tang

University of Western Australia

35 Sterling Hwy

Crawley WA 6009

Australia

Email: ecoadmin@biz.uwa.edu.au

The Economics Discussion Papers are available at:

Since 1980: $\quad$ https://ideas.repec.org/s/uwa/wpaper.html

Since 2004: http://www.business.uwa.edu.au/school/disciplines/economics

\begin{tabular}{|c|c|c|}
\hline \multicolumn{3}{|c|}{ ECONOMICS DISCUSSION PAPERS - 2016} \\
\hline $\begin{array}{l}\text { DP } \\
\text { NUMBER }\end{array}$ & AUTHORS & TITLE \\
\hline 16.01 & Xu, R., Wu, Y. and Luan, J. & $\begin{array}{l}\text { ANALYSIS OF FARMERS’ WILLINGNESS TO ADOPT } \\
\text { GENETICALLY MODIFIED INSECT-RESISTANT RICE IN } \\
\text { CHINA }\end{array}$ \\
\hline 16.02 & $\begin{array}{l}\text { Lia, Y., Fan, J., Zhao, D., Wu, Y. and } \\
\text { Li, J. }\end{array}$ & $\begin{array}{l}\text { TIERED GASOLINE PRICING: A PERSONAL CARBON } \\
\text { TRADING PERSPECTIVE }\end{array}$ \\
\hline 16.03 & Clements, K.W., Lan, Y. and Si, J. & UNCERTAINTY IN CURRENCY MISPRICING \\
\hline 16.04 & Parsons, C. and Vézina, P.L. & $\begin{array}{l}\text { MIGRANT NETWORKS AND TRADE:THE VIETNAMESE } \\
\text { BOAT PEOPLE AS A NATURAL EXPERIMENT }\end{array}$ \\
\hline 16.05 & Chang, S., Connelly, R. and Ma, P. & $\begin{array}{l}\text { WHAT WILL YOU DO IF I SAY ‘I DO’?: THE EFFECT OF } \\
\text { THE SEX RATIO ON TIME USE WITHIN TAIWANESE } \\
\text { MARRIED COUPLES }\end{array}$ \\
\hline 16.06 & Yu, F. and Wu, Y. & $\begin{array}{l}\text { BIASES IN PATENT EXAMINATION AND FIRMS’ } \\
\text { RESPONSES: EVIDENCE FROM THE } \\
\text { PHARMACEUTICAL INDUSTRY }\end{array}$ \\
\hline 16.07 & $\begin{array}{l}\text { Fan, J., Li, J., Wu, Y., Wang, S. and } \\
\text { Zhao, D. }\end{array}$ & $\begin{array}{l}\text { THE EFFECTS OF ALLOWANCE PRICE ON ENERGY } \\
\text { DEMAND UNDER A PERSONAL CARBON TRADING } \\
\text { SCHEME }\end{array}$ \\
\hline 16.08 & Golley, J., Tyers, R. and Zhou, Y. & $\begin{array}{l}\text { CONTRACTIONS IN CHINESE FERTILITY AND } \\
\text { SAVINGS: LONG RUN DOMESTIC AND GLOBAL } \\
\text { IMPLICATIONS }\end{array}$ \\
\hline 16.09 & McGrath, G. and Neill, K. & $\begin{array}{l}\text { FOREIGN AND DOMESTIC OWNERSHIP IN WESTERN } \\
\text { AUSTRALIA'S GAS MARKET }\end{array}$ \\
\hline 16.10 & Clements, K.W. and Si, J. & SIMPLIFYING THE BIG MAC INDEX \\
\hline 16.11 & Priyati, R.Y. and Tyers, R. & $\begin{array}{l}\text { PRICE RELATIONSHIPS IN VEGETABLE OIL AND } \\
\text { ENERGY MARKETS }\end{array}$ \\
\hline 16.12 & Wu, J., Wu, Y. and Wang, B. & $\begin{array}{l}\text { THE GREENNESS OF CHINESE CITIES: CARBON } \\
\text { DIOXIDE EMISSION AND ITS DETERMINANTS }\end{array}$ \\
\hline 16.13 & $\begin{array}{l}\text { Arslan, C., Dumont, J.C., Kone, Z., } \\
\text { Özden, Ç., Parsons, C. and } \\
\text { Xenogiani, T. }\end{array}$ & $\begin{array}{l}\text { INTERNATIONAL MIGRATION TO THE OECD IN THE } \\
\text { TWENTY-FIRST CENTURY }\end{array}$ \\
\hline 16.14 & Tomioka, K. and Tyers, R. & $\begin{array}{l}\text { HAS FOREIGN GROWTH CONTRIBUTED TO } \\
\text { STAGNATION AND INEQUALITY IN JAPAN? }\end{array}$ \\
\hline
\end{tabular}




\begin{tabular}{|c|c|c|}
\hline 16.15 & Donovan, J. and Hartley, P. & $\begin{array}{l}\text { RIDING THE IRON ORE CYCLE: ACTIONS OF } \\
\text { AUSTRALIA'S MAJOR PRODUCERS }\end{array}$ \\
\hline 16.16 & Czaika, M. and Parsons, C. & $\begin{array}{l}\text { HIGH-SKILLED MIGRATION IN TIMES OF GLOBAL } \\
\text { ECONOMIC CRISIS }\end{array}$ \\
\hline 16.17 & Lefroy, T., Key, J. and Kingwell, R. & $\begin{array}{l}\text { A LONGITUDINAL EXAMINATION OF BROADACRE } \\
\text { FARM SIZE AND PERFORMANCE IN WESTERN } \\
\text { AUSTRALIA }\end{array}$ \\
\hline 16.18 & Arthmar, R. and McLure, M. & $\begin{array}{l}\text { SRAFFA, MYRDAL AND THE } 1961 \text { SÖDERSTRÖM GOLD } \\
\text { MEDAL }\end{array}$ \\
\hline 16.19 & Azwar, P. and Tyers, R. & $\begin{array}{l}\text { POST-GFC EXTERNAL SHOCKS AND INDONESIAN } \\
\text { ECONOMIC PERFORMANCE }\end{array}$ \\
\hline 16.20 & Chen, A. and Groenewold, N. & $\begin{array}{l}\text { OUTPUT SHOCKS IN CHINA: DO THE DISTRIBUTIONAL } \\
\text { EFFECTS DEPEND ON THE REGIONAL SOURCE? }\end{array}$ \\
\hline 16.21 & Wu, Y., Zhu, X. and Groenewold, N. & $\begin{array}{l}\text { THE DETERMINANTS AND EFFECTIVENESS OF } \\
\text { INDUSTRIAL POLICY IN CHINA: A STUDY BASED ON } \\
\text { FIVE-YEAR PLANS }\end{array}$ \\
\hline 16.22 & Liu, H. & $\begin{array}{l}\text { THE INCOME AND PRICE SENSITIVITY OF DIETS } \\
\text { GLOBALLY }\end{array}$ \\
\hline 16.23 & Asano, A., Neill, K. and Yamazaki, S. & $\begin{array}{l}\text { DECOMPOSING FISHING EFFORT: MODELLING THE } \\
\text { SOURCES OF INEFFICIENCY IN A LIMITED-ENTRY } \\
\text { FISHERY }\end{array}$ \\
\hline 16.24 & Golley, J., Tyers, R. and Zhou, Y. & $\begin{array}{l}\text { FERTILITY AND SAVINGS CONTRACTIONS IN CHINA: } \\
\text { LONG-RUN GLOBAL IMPLICATIONS }\end{array}$ \\
\hline 16.25 & Taylor, G., Tyers, R. & $\begin{array}{l}\text { SECULAR STAGNATION: DETERMINANTS AND } \\
\text { CONSEQUENCES FOR AUSTRALIA }\end{array}$ \\
\hline
\end{tabular}

\begin{tabular}{|c|c|c|}
\hline \multicolumn{3}{|c|}{ ECONOMICS DISCUSSION PAPERS - 2017} \\
\hline $\begin{array}{l}\text { DP } \\
\text { NUMBER }\end{array}$ & AUTHORS & TITLE \\
\hline 17.01 & Tyers, R. and Zhou, Y. & $\begin{array}{l}\text { AUTOMATION AND INEQUALITY WITH TAXES AND } \\
\text { TRANSFERS }\end{array}$ \\
\hline 17.02 & Ye, L. and Robertson, P. & $\begin{array}{l}\text { HITTING THE GREAT WALL: RURAL-URBAN } \\
\text { MIGRATION AND CHINA'S GROWTH SLOWDOWN }\end{array}$ \\
\hline 17.03 & Ye, L. and Robertson, P. & $\begin{array}{l}\text { MIGRATION AND GROWTH IN CHINA: A SCEPTICAL } \\
\text { ASSESSMENT OF THE EVIDENCE }\end{array}$ \\
\hline 17.04 & Clements, K. Si, J. and Vo, L. & $\begin{array}{l}\text { FOOD AND AGRICULTURAL PRICES ACROSS } \\
\text { COUNTRIES AND THE LAW OF ONE PRICE }\end{array}$ \\
\hline 17.05 & $\begin{array}{l}\text { Chen, M., Clements, K., Gao, G. and } \\
\text { Si, J. }\end{array}$ & THREE FACTS ABOUT WORLD METAL PRICES \\
\hline 17.06 & $\begin{array}{l}\text { Cornes, R., Fiorini, L. and } \\
\text { Maldonado, W. }\end{array}$ & $\begin{array}{l}\text { EXPECTATIONAL STABILITY IN AGGREGATIVE } \\
\text { GAMES }\end{array}$ \\
\hline 17.07 & Hartley, P. & $\begin{array}{l}\text { THE COST OF DISPLACING FOSSIL FUELS: SOME } \\
\text { EVIDENCE FROM TEXAS }\end{array}$ \\
\hline 17.08 & Shehabi, M. R. & ASSESSING KUWAITI ENERGY PRICINING REFORMS \\
\hline 17.09 & Perdana, S. and Tyers, R. & $\begin{array}{l}\text { GLOBAL CLIMATE CHANGE MITIGATION: STRATEGIC } \\
\text { INTERACTION OR UNILATERAL GAINS? }\end{array}$ \\
\hline 17.10 & McLure, M. & $\begin{array}{l}\text { RICARDIAN EQUIVALENCE, THE ITALIAN FISCAL } \\
\text { TRADITION AND WA GOVERNMENT NET DEBT }\end{array}$ \\
\hline 17.11 & Trinh, J. & $\begin{array}{l}\text { THE PARETO DISTRIBUTION AND ITS RELATIONSHIP } \\
\text { TO PIKETTY'S THIRD FUNDAMENTAL LAW OF } \\
\text { CAPITALISM }\end{array}$ \\
\hline
\end{tabular}




\begin{tabular}{|c|c|c|}
\hline 17.12 & McLure, M. & $\begin{array}{l}\text { THINKING OUTSIDE THE BOX: A NEW HISTORY OF } \\
\text { EDGEWORTH'S AND PARENTO'S DEVELOPMENT OF } \\
\text { THE BOX DIAGRAM }\end{array}$ \\
\hline 17.13 & Zhou, Y. and Tyers, R. & AUTOMATION AND INEQUALITY IN CHINA \\
\hline 17.14 & Arthmar, R. and McLure, M. & $\begin{array}{l}\text { THE ECONOMIC AND SOCIAL CONSEQUENCES OF THE } \\
\text { WAR: PIGOU, THE PRESS AND THE STRUGGLE FOR AN } \\
\text { HONOURABLE PEACE }\end{array}$ \\
\hline 17.15 & Shehabi, M. R. & $\begin{array}{l}\text { CONTEMPORARY KUWAITISATION DYNAMICS AND } \\
\text { THEIR HISTORICAL PERSPECTIVES }\end{array}$ \\
\hline 17.16 & Clements, K. and Si, J. & $\begin{array}{l}\text { WHAT DO AUSTRALIAN ECONOMICS PhDs DO? THE } \\
\text { UWA EXPERIENCE }\end{array}$ \\
\hline 17.17 & Arthmar, R. and McLure, M. & KEYNES AND THE ROYAL SWEDISH ACADEMY \\
\hline 17.18 & Chen, A. and Groenewold, N. & $\begin{array}{l}\text { CHINA'S ‘NEW NORMAL’: IS THE GROWTH } \\
\text { SLOWDOWN DEMAND- OR SUPPLY- DRIVEN? }\end{array}$ \\
\hline 17.19 & Groenewold, N. & $\begin{array}{l}\text { CHINA'S 'NEW NORMAL': HOW WILL CHINA'S } \\
\text { GROWTH SLOWDOWN AFFECT AUSTRALIA'S } \\
\text { GROWTH? }\end{array}$ \\
\hline
\end{tabular}

ECONOMICS DISCUSSION PAPERS - 2018

\begin{tabular}{|c|c|c|}
\hline $\begin{array}{c}\text { DP } \\
\text { NUMBER }\end{array}$ & AUTHORS & TITLE \\
\hline 18.01 & Tyers, R. and Zhou, Y. & LOST INFLATION? \\
\hline 18.02 & McLure, M. & PARETIAN FISCAL SOCIOLOGY \\
\hline 18.03 & McLure, M. and Montesano, A. & $\begin{array}{l}\text { THINKING OUTSIDE THE BOX: EDGEWORTH, PARETO } \\
\text { AND THE EARLY HISTORY OF THE BOX DIAGRAM }\end{array}$ \\
\hline 18.04 & Tyers, R. and Zhou, Y. & DEFLATION FORCES AND INEQUALITY \\
\hline 18.05 & Clements, K. and Si, J. & DIVISIA AND FRISCH ARE FRIENDS \\
\hline 18.06 & Trinh, J. and McLure, M. & $\begin{array}{l}\text { PILETTY'S ( } \mathrm{r}-\mathrm{g} \text { ) LAW IS PARETO'S LAW: CONSISTENT } \\
\text { ANALYSES OF INCOME DISTRIBUTION PREDICATED ON } \\
\text { INCONSISTENT DEFINITIONS OF INEQUALITY }\end{array}$ \\
\hline 18.07 & Tyers, R. and Zhou, Y. & $\begin{array}{l}\text { AUTOMATION, TAXES AND TRANSFERS } \\
\text { WITH INTERNATIONAL RIVALRY }\end{array}$ \\
\hline 18.08 & Li, Q., Vo, L. H. and Wu, Y. & INTANGIBLE CAPITAL DISTRIBUTION IN CHINA \\
\hline 18.09 & Vo, L. H. & $\begin{array}{l}\text { WHY DON'T AGRICULTURAL PRICES ALWAYS ADJUST } \\
\text { TOWARDS PARITY? }\end{array}$ \\
\hline
\end{tabular}

